NBER WORKING PAPER SERIES

\title{
DO APPEALS TO DONOR BENEFITS RAISE MORE MONEY THAN APPEALS TO RECIPIENT BENEFITS? EVIDENCE FROM A NATURAL FIELD EXPERIMENT WITH PICK.CLICK.GIVE.
}

\author{
John A. List \\ James J. Murphy \\ Michael K. Price \\ Alexander G. James \\ Working Paper 26559 \\ http://www.nber.org/papers/w26559
}

\author{
NATIONAL BUREAU OF ECONOMIC RESEARCH \\ 1050 Massachusetts Avenue \\ Cambridge, MA 02138 \\ December 2019
}

Special thanks are due Heather Beatty at Pick.Click.Give., Ian Dutton and Diane Kaplan at the Rasmuson Foundation for their enthusiasm and support for this project, and to the Alaska Permanent Fund Division for providing the data. Financial support for this project was provided by the Rasmuson Foundation and the John Templeton Foundation through the Science of Philanthropy Initiative. The views expressed herein are those of the authors and do not necessarily reflect the views of the National Bureau of Economic Research.

NBER working papers are circulated for discussion and comment purposes. They have not been peer-reviewed or been subject to the review by the NBER Board of Directors that accompanies official NBER publications.

(C) 2019 by John A. List, James J. Murphy, Michael K. Price, and Alexander G. James. All rights reserved. Short sections of text, not to exceed two paragraphs, may be quoted without explicit permission provided that full credit, including ()$^{\text {notice, }}$ is given to the source. 
Do Appeals to Donor Benefits Raise More Money than Appeals to Recipient Benefits? Evidence from a Natural Field Experiment with Pick.Click.Give.

John A. List, James J. Murphy, Michael K. Price, and Alexander G. James

NBER Working Paper No. 26559

December 2019

JEL No. C93,D03,D64,H41,L3

\section{ABSTRACT}

We partnered with Alaska's Pick.Click.Give. Charitable Contributions Program to implement a statewide natural field experiment with 540,000 Alaskans designed to explore whether targeted appeals emphasizing donor benefits through warm glow impact donations. Results highlight the relative import of appeals to self. Individuals who received such an appeal were 4.5 percent more likely to give and gave 20 percent more than counterparts in the control group. Yet, a message that instead appealed to recipient benefits had no effect on average donations relative to the control group. We also find evidence of long-run effects of warm glow appeals in the subsequent year.

John A. List

Department of Economics

University of Chicago

1126 East 59th

Chicago, IL 60637

and NBER

jlist@uchicago.edu

James J. Murphy

Department of Economics

University of Alaska Anchorage

3211 Providence Drive

Anchorage, AK 99058

murphy@uaa.alaska.edu
Michael K. Price

Department of Economics, Finance, and Legal Studies

The University of Alabama

250 Alston Hall

Box 870224

Tuscaloosa, AL 35487

and NBER

mkprice2@cba.ua.edu

Alexander G. James

Department of Economics

University of Alasaka Anchorage

3211 Providence Drive

Anchorage, AK 99058

ajames27@alaska.edu 


\section{Introduction}

Charitable organizations play an important role in modern economies, providing invaluable public goods and employment opportunities for millions nationwide. As far back as the mid-1800s, the sector has recognized the importance that private individuals play in financing their operations. In the United States today there are more than 1.5 million registered nonprofit organizations that receive cash contributions exceeding two percent of GDP annually. In fact, growth of the sector has outperformed the S\&P 500 over the past several decades (List, 2011). Notwithstanding, experts predict that the sector will grow in importance as aging populations and devolutionary trends in government cause increased reliance on the goods and services of nonprofits.

Not surprisingly, these challenges have prompted a tremendous amount of research on the primitives of the economics of charity and the relationship between charities and potential donors. Much of this work has focused on the impact of different fund-raising techniques and the associated impact on both the number of donors and overall contribution levels. ${ }^{1}$ Our study builds on this body of work and takes as inspiration the lot of studies that show the importance of warm glow (see, e.g., Andreoni, 1995; Crumpler and Grossman, 2008; Null, 2011; Tonin and Vlassopoulos, 2010; Imas, 2014; Tonin and Vlassopoulos, 2014; Singh et al., 2019). ${ }^{2}$

In this spirit, we designed a natural field experiment embedded within the state of Alaska's Permanent Fund Dividend Charitable Contributions Program or Pick.Click.Give. (www.pickclickgive.org). ${ }^{3}$ As part of the 2014 fundraising campaign, we randomly allocated the approximate 290,000 households in the state into either a control group or one of two treatment groups that received a postcard promoting Pick.Click.Give. Both postcards included a normative appeal but differed in whether the message highlighted either benefits to self ("Warm Your Heart") or benefits to others ("Make Alaska Better for Everyone"). The slogans were designed to reflect

\footnotetext{
${ }^{1}$ Such studies cover topics including: (i) matching gifts and rebates (Chen et al., 2006; Eckel and Grossman, 2006; Karlan and List, 2007; Meier, 2007; Huck and Rasul, 2011; Scharf and Smith, 2014), (ii) charitable auctions and lotteries (Morgan, 2000; Goeree et al., 2005; Landry et al., 2006; Carpenter et al., 2008; Elfenbein and McManus, 2010), (iii) social comparisons (Frey and Meier, 2004; Shang and Croson, 2009), (iv) thank you gifts (Falk, 2007; Alpizar et al., 2008; Eckel et al., 2014), (v) peer solicitations (Meer, 2011; Castillo et al., 2014; Smith et al., 2013), and (vi) seed money announcements (Andreoni, 1998; List and Lucking-Reiley, 2002; Vesterlund, 2003; Potters et al., 2007; Bracha et al., 2011).

${ }^{2}$ A related body of work in marketing explores the effectiveness of solicitation appeals highlighting benefits to self (see, e.g., Brunel and Nelson, 2000; Peloza and White, 2009; Feiler et al., 2012; Baek et al., 2019).

${ }^{3}$ Pick.Click.Give. was established in 2009 as a way for Alaskans to share some of their annual Permanent Fund Dividend (PFD) with eligible nonprofits throughout the state. Donors simultaneously choose the amount to give and to which charities.
} 
the two main motives for charitable giving - concerns for the benefits to self (impure altruism or "warm glow") and concerns for the benefits to others (pure altruism) - and provide a means to disentangle their relative importance. ${ }^{4}$

Postcards were mailed during the last week of December 2013 and we received information on donations for each of the more than 540,000 individuals who registered for their 2014 Permanent Fund Dividend online. We observe donations in excess of \$3.1 million coming from more than 26,000 unique individuals. To explore whether our messages influenced long-run patterns of giving, we augment our data to include information on contributions through Pick.Click.Give. in 2015.

Results from our experiment highlight the relative importance of benefits to self on donation decisions. Individuals who received the "Warm Your Heart" message were approximately 4.5 percent more likely to give and their contributions were 20 percent larger than in the control group. Messages that highlighted the benefit to others increased the propensity to give, but had no effect on average donation size. Interestingly, similar data patterns are observed for both warm-list households (those who contributed through Pick.Click.Give. in 2013) and coldlist counterparts (who did not give in 2013). Treatment effects on both the propensity to give and on average donation size were, however, more pronounced amongst cold-list which suggests that normative appeals are an effective way to attract new donors.

Exploring other heterogeneities, we find that women and those age 50 and over were more likely to give and provided larger average gifts than others. However, conditional on giving, men provided larger gifts. Such differences share similarities to data from List (2004). Moreover, these data patterns suggest that the distribution of altruism for women was less disperse than the distribution for men; a pattern identified by structural estimates in Della Vigna et al. (2013). Finally, as in Landry et al. (2010), we find that prior donors were more likely to give and provided larger average gifts than cold-list counterparts.

Given past work showing the relative impermanence of behavioral interventions (e.g., Gneezy and List, 2006; Landry et al., 2010; Ferraro and Price, 2013; Allcott and Rogers, 2014) and the importance charitable organizations place on building a long-term relationship with

\footnotetext{
${ }^{4}$ Although the warm-glow model (Andreoni, 1989; 1990) is the canonical example, other models that focus on the relative importance of benefits to self include work on social pressures (e.g., Della Vigna et al., 2012; Knutsson et al., 2013; Andreoni et al., 2017) and social identity (Benjamin et al., 2010; Kessler and Milkman, 2014).
} 
donors, it is important to explore whether the effects of our targeted messages are sustained across campaigns and impacted long-run patterns of giving. To shed insights into the long-run impacts, we examine whether treatment assignment in 2014 impacted contributions through Pick.Click.Give. during the 2015 campaign. Results for this analysis suggest that our intervention impacted long-run patterns of giving - those who received the "Warm Your Heart" message were more likely to give and provided larger contributions in the subsequent 2015 campaign than others. Yet, for warm-list donors, the effectiveness of our "nudge" waned over time and the impact on giving in the 2015 campaign was significantly less pronounced than what was observed during the 2014 campaign. For cold-list donors, treatment effects were more persistent and suggest that receiving the benefits to self message had long-lasting effects.

Our paper contributes to several different literatures. First, our paper contributes to a growing body of work incorporating insights from behavioral economics such as the power of defaults (Goswami and Urminsky, 2016; Altmann et al., 2019) or time inconsistency (Breman, 2011; Andreoni and Serra-Garcia, 2016) into solicitation appeals. However, our paper extends the previous work along two dimensions. To the best of our knowledge, we are the first to explore the impact of targeted messages and normative appeals on charitable giving in a natural field experiment. In this regard, our paper shares similarity with a body of work exploring the impact of social information on contributions to a charity or online message board (e.g., Frey and Meier, 2004; Croson and Shang, 2009; Shang and Croson, 2009; Chen et al., 2010; Smith et al., 2013; Chen et al., 2017; Gallus, 2017). Moreover, prior work has focused on behavior in the context of a fund-raising drive to explore how various strategies affect giving to the associated charitable cause. Our study, in contrast, explores behavior in the context of a government-sponsored program designed to encourage giving to a range of eligible charitable organizations and how our messages impacted aggregate patterns of giving through this program.

Second, our paper contributes to a body of research in marketing and social psychology exploring the impact of self- and other-benefit appeals on charitable donations (e.g., Fisher et al., 2008; White and Peloza, 2009; Feiler et al., 2012; Baek et al., 2019). However, much of this literature relies upon laboratory experiments and hypothetical decisions such as statements about one's intention to/likelihood of donating to a given cause. Moreover, the aim of this literature is to explore whether factors such as self-image concerns, public observability, or social exclusion 
moderate the effectiveness of such appeals. Our paper extends this literature by exploring the impact of such appeals on both contemporaneous and long-run patterns of giving.

Third, our findings contribute to the literature on social norms and the use of normative appeals as a means to promote behavioral change. To date, this literature has largely focused on using such appeals to influence outcomes such as retirement savings and the use of credit (Beshears et al., 2015; Seira et al., 2017), tax compliance (Fellner et al., 2013; Hallsworth et al., 2017), traffic violations (Chen et al., 2017), or the amount of water or energy used by residential households (Allcott, 2011; Costa and Kahn, 2013; Ferraro and Price, 2013; Allcott and Rogers, 2014; Brent et al., 2015; Ito et al., 2018). In our study, however, we concentrate on participation in a governmentsponsored program and subsequent patterns of charitable giving through this program. In this regard, our study is closest in spirit to an emerging literature that explores the use of social norms to induce participation in in-home energy audits as a means to promote the adoption of improved technologies (Hahn et al., 2016; Holladay et al., 2019; Allcott and Greenstone, 2017).

Fourth, our paper contributes to a literature exploring the economic impacts of permanent cash transfers such as Alaska's Permanent Fund Dividend payments. To date, this literature has focused on how receipt of the PFD payments impact outcomes such as intertemporal patterns of consumption (Hsieh, 2003; Kueng, 2015), short-term mortality (Evans and Moore, 2011), aggregate employment (Jones and Marinescu, 2018), or crime (Watson, Guettabi, and Reimer, 2019). We extend this literature by exploring how the PFD payments influence charitable giving and the private provision of public goods.

Finally, our paper contributes to a literature that sets forth to identify the underlying motives for charitable giving. Broadly speaking, such studies focus on two main drivers of behavior - concerns for the benefits to self or concerns for the benefits to others - and attempt to disentangle the motives by testing the extent to which donations by others are a substitute for one's own gifts. For example, there is a rich body of work that relies upon variation in the gifts of others/government funding to test for crowding (e.g., Kingma, 1989; Andreoni, 1993; Payne, 1998; Andreoni and Payne, 2003, 2011; Eckel et al., 2005; Crumpler and Grossman, 2008; Andreoni et al., 2104; Ottoni-Wilhelm et al., 2017). Although such an approach tests the defining characteristic of the pure altruism model (complete crowding), identification requires strong assumptions regarding fund-raising effort and what is known by potential donors regarding the gifts of others. Our study provides an alternate approach to disentangle the relative importance of 
benefits to self and benefits to others - the use of targeted messages that make salient a given motive.

\section{Alaska's Permanent Fund and Pick.Click.Give.}

Every fall, Alaskans receive an annual payment known as the Permanent Fund Dividend (PFD), which represents their share of the earnings the state receives from investing revenues from oil production. The source of these payments, the Alaska Permanent Fund, is a sovereign wealth fund created by an amendment to the state constitution in 1976 as a way to share returns from the extraction of the state's oil resources with future generations. In 2014, the fund had around \$50 billion in assets that were invested in a diverse portfolio managed by an independent state agency charged with maximizing long-term income. ${ }^{5}$

Any individual (including children) who was a resident of Alaska for the entire calendar year prior, and who declares an intent to remain in the state indefinitely, is eligible to receive a dividend. The registration period begins every January $1^{\text {st }}$ and continues through the final day of March with distribution of the PFD occurring in early October. Potential recipients must register for the Permanent Fund on an annual basis to confirm their eligibility.

The total amount distributed each year is based on a five-year average of earnings for the Permanent Fund. The total amount is then divided equally amongst all eligible recipients. ${ }^{6}$ The first PFD for $\$ 1000$ was issued in 1982. Since then, the annual distributions have varied annually with the per person payments ranging from a low of \$331.29 in 1984 to a high of $\$ 2,072$ in 2015; see Figure 1.

Although the PFD arrives as a lump-sum payment, Hsieh (2003) found no evidence that consumption patterns are sensitive to PFD disbursements suggesting that the payments are integrated into disposable income. In part, this reflects that Alaskans have a rough idea of what the upcoming dividend payments will be when the application period opens each January. Local media

\footnotetext{
${ }^{5}$ See http://www.apfc.org for more information on the Permanent Fund.

${ }^{6}$ The use of a five year average to determine disbursements is designed to (i) reduce fluctuations in the annual dividend payments due to volatility in the stock market and (ii) reduce incentives to manage funds for short-term gains (Goldsmith, 2010).
} 
typically provide estimates of the coming year's PFD amount, providing individuals information that can be used to integrate the dividend into the household budget. ${ }^{7}$

A more recent body of work calls into question the assumption that PFD disbursements are integrated into disposable income. For example, Kueng (2018) provides evidence that variations in PFD disbursements have a significant impact on the purchase of nondurable goods. Similarly, Jones and Marinescu (2018) provide evidence that while PFD disbursements have no impact on aggregate employment, there are sizeable effects of the disbursements on employment and parttime work in the non-tradeable sector; a pattern of results they note is consistent with PFD disbursements leading to consumption increases that stimulate labor demand. Given this evidence, it is interesting to examine whether, and to what extent, one can stimulate individuals to share PFD disbursements with nonprofits in the state.

\section{The Permanent Fund Charitable Contributions Program: Pick.Click. Give.}

Historically, nonprofits around the state of Alaska were able to finance their operations largely through corporate largesse and government earmarks. Faced with the national economic downturn and declining state oil revenues, Alaskan nonprofits have had to develop a new model of funding that includes increased focus on private provision. ${ }^{8}$ To facilitate this change, the state of Alaska introduced the Permanent Fund Charitable Contributions Program (better known as Pick.Click.Give.) in 2009 as a way to promote individual giving to nonprofits throughout the state. The program was established as a three-year pilot project after which it was incorporated into the Permanent Fund Dividend program. Pick.Click.Give. was managed by the Rasmuson Foundation until 2015 when management of the program was turned over to the Alaska Community Foundation. At that time, the state legislature instituted a coordination fee whereby 7 percent of all donations would be used to cover the costs of administering the program.

Pick.Click.Give. allows individuals to voluntarily donate any portion of their Permanent Fund Dividend to eligible nonprofits of their choice. The eligibility requirements for nonprofit

\footnotetext{
${ }^{7}$ For example, in September 2013, the Anchorage Daily News projected an approximately $\$ 1800$ dividend for 2014 (the year of our study) which was not much different than the \$1884 dividend actually paid in October 2014. http://www.adn.com/article/20130927/bigger-dividend-checks-likely-permanent-fund-swells-43-billion-2013

${ }^{8}$ According to data from the Urban Institute, Alaska has one of the lowest rates of giving of any state in the nation. For example, the average contribution in 2013 for a household that itemized their tax return was $\$ 869$ or approximately $1.4 \%$ of their overall income - a figure that ranked $47^{\text {th }}$ nationwide. https://www.urban.org/sites/default/files/publication/77671/2000608-Profiles-of-Individual-CharitableContributions-by-State-2013.pdf
} 
organizations include that (i) the organization was qualified as an exempt 501(c)(3) organization for at least two years prior to the application, (ii) the organization is directed by a voluntary board of directors or an advisory board for which a majority of the members are residents of the state, and (iii) the organization receives at least $\$ 100 \mathrm{~K}$ or five percent of its total annual receipts from charitable contributions. Eligible organizations provide a diverse array of services that span seven main sectors; (i) youth services and education, (ii) emergency response for victims of crime, (iii) humanitarian services, (iv) animal shelters and zoos, (v) arts and culture, (vi) health services, and (vii) community based services and organizations. In 2014, a total of 512 nonprofit organizations from more than 50 communities around Alaska registered and received contributions through Pick.Click.Give. ${ }^{9}$

To be eligible to give through Pick.Click.Give, individuals must register for the Permanent Fund Dividend online. ${ }^{10}$ Once the online PFD application is complete, individuals are provided a link that guides them to a website where they can pledge donations through Pick.Click.Give. Contributions made through Pick.Click.Give. are deducted from the individual's PFD return and sent directly to the nonprofit by the Permanent Fund Division.

The minimum allowable donation is $\$ 25$, and increases in $\$ 25$ increments up to the full amount of the dividend payment. Since the exact amount of the PFD is not known at the time of registration, donors who select multiple organizations to support must prioritize them. If total pledges exceed the PFD, donations are processed in order of priority until the PFD is exhausted. Although the PFD registration closes at the end of March, individuals can update their pledges through Pick.Click.Give. through the end of August, at which time the pledge becomes a binding commitment. Contributions made through the program are tax deductible and donors have the option, when making their pledge, to check a box authorizing the state to send their name and contact information to the organizations they have chosen to support.

Table 1 provides information on both the rate of participation and aggregate donations for the first five years of the program (2009 through 2013). As noted in the table, both participation rates and aggregate donations have grown steadily over time. For example, whereas aggregate contributions in 2009 totaled $\$ 400,000$, this figure increased more than five-fold by 2013, when

\footnotetext{
${ }^{9}$ This represents an approximate 8.5 percent increase in the number of eligible recipients relative to the 2013 campaign and an approximate 39 percent increase in the number of eligible recipients since the program's inception in 2009.

${ }^{10}$ In 2014, the year of our study, approximately 83 percent of all individuals who registered for the PFD did so online and were thus eligible to give through Pick.Click.Give.
} 
aggregate contributions totaled more than $\$ 2.3$ million. During the first five years of the program (2009-2013), Alaskan's contributed nearly \$6.8 million to nonprofits throughout the state, which accounts for nearly one percent of overall contributions to nonprofit organizations throughout the state over this time period. ${ }^{11}$

\section{Experimental Design and Results}

As aforementioned, there is a vibrant literature that explores the demand side of charitable fundraising (see, e.g., Andreoni, 1995; List and Lucking-Reiley, 2002; Null, 2011; OttoniWhilhelm, 2017; Singh et., 2019). Our goal is to extend this work to the Pick.Click.Give. environment by leveraging the spirit of warm glow to examine whether targeted messages and normative appeals affect donor behavior in a manner that is consonant with warm glow. To do so, we designed a natural field experiment as part of the 2014 Pick.Click.Give. marketing campaign. We randomly assigned every household in Alaska into either a control group (no postcard) or one of two treatment groups that received a postcard that included a normative slogan designed to highlight one of two main motivations for charitable giving - concerns for the benefits to self (impure altruism or "warm-glow") or concerns for the benefits to others (pure altruism). ${ }^{12}$ As state law prohibited the Permanent Fund Division from providing address-level data, randomization occurred at the zip code level.

In each treatment, households in pre-determined zip codes throughout the state of Alaska were sent a postcard during the final week of December 2013. Importantly, every household within a treatment zip code was mailed the assigned a postcard (see Figures 2 and 3). All postcards contained information about Pick.Click.Give. and urged the recipient to share their Permanent Fund Dividend. In addition, the front of each postcard contained a picture of either a heart or an outline of the state of Alaska within which was written a corresponding message - "Warm your heart. Share your PFD" or "Make Alaska better for everyone. Share your PFD”. These same appeals were printed on the back of the postcard along with a montage showing pictures of various Alaska residents.

\footnotetext{
${ }^{11}$ Data on charitable giving in Alaska comes from a report by the Urban Institute profiling charitable giving across different states, see, https:/www.urban.org/sites/default/files/publication/77671/2000608-Profiles-of-IndividualCharitable-Contributions-by-State-2013.pdf

12 In this regard, our design and messages share similarity with work in marketing and social psychology exploring the relative impact of self-benefit and other-benefit messages on altruism and pro-social behavior (e.g., White and Peloza, 2009; Feiler et al., 2012; Baek et al., 2019).
} 
Table 2 summarizes our experimental design and corresponding sample size for each treatment. As noted Panel B, our control group included data for 169,441 individuals living in one of 89 distinct zip codes around the state. The benefits to others ("Make Alaska better for everyone") treatment included data for 187,468 individuals residing in one of 90 distinct zip codes around the state. The benefits to self ("Warm your heart") treatment included data for 183,215 individuals residing in one of 89 distinct zip codes around the state.

Figure 4 provides a map of Alaska and shows the spatial distribution of our various treatment groups throughout the state. Anchorage, Juneau, Fairbanks, and Kodiak Island had multiple zip codes; each of the other communities only had a single zip code and were thus exposed to a single treatment condition. Figure 5 shows the spatial distribution of treatments for these statistical areas.

Before proceeding to the results section, we should highlight a few important design issues. First and foremost, privacy laws prohibited the Permanent Fund Division from releasing addresslevel data for individuals that registered for the Permanent Fund Dividend. We were thus forced to randomize at the zip code level which was the finest geographic indicator in the data. Second, data for the experiment was provided by the Permanent Fund Division and includes a unique ID code for every person who registered for a PFD along with (i) the date they registered for the PFD, (ii) the filing method - mail or electronic, (iii) the name of any charity supported along with the associated pledge amount, (iv) the age and gender of the individual, and (v) zip codes associated with the individual's home residence and mailing address. We used data from 2013 to assign zip codes to treatments and ensure balance along observable dimensions.

Third, only those individuals who registered for the PFD online were eligible to donate through Pick.Click.Give. We thus restrict our sample to the subset of individuals (83.3\% in 2014) who registered online. Fourth, households were assigned to treatment based on the zip from their mailing address. For about $82 \%$ of the sample, the home and mailing zips are the same. However, as college students, Olympic athletes and active duty military are eligible for the PFD, we observe a small fraction of individuals for whom these zips do not match. In addition, people with post office boxes usually have different mailing and physical addresses. Finally, we cannot observe whether a given individual received a postcard, so we assign treatment based on the mailing zip listed in the data. Our estimates thus capture an intent-to-treat effect and provide a lower bound of the "true" effect of treatment. 


\section{Experimental Findings: Overall Patterns of Giving}

Panel B of Table 2 presents summary statistics for our experiment. For example, in 2014 we observe 169,441 individuals in our control group. Of these 4.4\% (or 7,552) elected to donate a portion of their Permanent Fund Dividend. The average contribution for individuals in the control group is $\$ 4.77$ which corresponds to $\$ 807,548$ in aggregate contributions. In total, approximately $4.9 \%$ of all individuals made a donation and Pick.Click.Give. raised more than $\$ 3.1$ million ( $\sim 5.79$ per person) for eligible nonprofits throughout the state. ${ }^{13}$ Relative to the 2013 campaign, these figures correspond to an approximate 9.3 percent increase in the total number of donors and a 23.9\% increase in total dollars raised (which partly reflects an increase in PFD registration from 2013). For perspective, total charitable contributions by Alaska residents in 2014 was just under \$260 million dollars. Hence, donations made through Pick.Click.Give. in 2014 accounted for approximately 1.2 percent of total giving statewide.

Disaggregating the data further and exploring outcomes at the charity level, 512 registered organizations received at least one donation. ${ }^{14}$ However, we observe significant heterogeneity across organizations in terms of both the number of donations and total dollars received. For example, in 2014 organizations received donations, on average, from approximately 88 individuals. Yet, we observe 48 charities that received donations from 10 or fewer people and another 40 that received donations from at least 200 individuals. We observe similar heterogeneity across charities in terms of dollars received. The average amount received was approximately $\$ 6,400$, there were 36 organizations that received $\$ 500$ or less and another 29 organizations that received $\$ 20,000$ or more in total gifts.

Table A1 in the appendix summarizes the 20 most popular recipients in terms of number of donations (upper panel) and dollars received (lower panel) along with information on the cause type for each of the charities. As noted in the table, 16 organizations appear amongst the 20 most popular in terms of both the number of donations and donation amounts. Moreover, we observe a distinct skewness in the distribution of gifts across charitable organizations. Whereas the top

\footnotetext{
13 The total amount disbursed via the PFD in 2014 was approximately $\$ 1.2$ billion. Contributions in our experiment thus account for approximately $0.3 \%$ of this total.

${ }^{14}$ Recall that individuals are allowed to contribute to more than one charitable cause. During the 2014 campaign, we observe a total of 44,978 contributions received from 26,610 unique donors.
} 
twenty organizations receive nearly 35 percent of donations and 38 percent of overall dollars, the five most popular charities account for more than half of these amounts. In fact, the most popular recipient in terms of both the number of donations and dollars, Bean's Café, received more than five percent of all total donations and dollars. ${ }^{15}$

\section{Do Targeted Messages Work? Exploring Treatment Effects}

There is a growing body of work showing that targeted messages and normative appeals can influence an array of pro-social behaviors. Our data are sufficiently rich to explore whether framing who benefits from such actions influences the efficacy of such appeals. Evidence for such comparison is contained in Table 3. As noted in the table, individuals residing in a zip code that received our benefits to self message were approximately $29.5 \%$ more likely to give $(5.7 \%$ versus $4.4 \%$ ) than were counterparts in the control group. Moreover, average contributions for those in the benefits to self treatment were approximately $54.4 \%$ greater $(\$ 7.35$ versus $\$ 4.76)$ than that observed for the control group. Figure 6 complements these data and provides a graphical depiction of differences across treatments; the figures highlight that both participation rates and average contributions are higher for individuals living in zip codes that received the benefits to self postcard than for counterparts living in our control zip codes. These data lead to our first set of results and provide evidence that targeted messages, particularly those that emphasize warm-glow motivations, do influence charitable contributions:

Result 1: Individuals receiving the benefits to self message ("Warm Your Heart”) were more likely to give and provided larger gifts than those in the control group.

This first result shares similarity with prior work showing the influence of normative appeals on behaviors such as environmental conservation (Goldstein et al., 2008; Nolan et al., 2008; Ferraro and Price, 2013), honesty in markets (Pruckner and Sausgruber, 2013), or tax compliance (Hallsworth et al., 2017). Result 1 also shares similarity with work in marketing showing that selfbenefit appeals increase the frequency with which laboratory subjects express willingness (or likelihood) of supporting a charitable cause (White and Peloza, 2009; Fieler et al., 2012; Baek et al., 2019). More broadly, our data suggests the importance of self-interests as a driver of donor

\footnotetext{
${ }^{15}$ Bean's Café is a nonprofit organization located in Anchorage whose mission is to “...feed the hungry and homeless without discrimination during the day."
} 
behavior; a finding consonant with prior work showing the importance of motives such as prestige and concerns for social image (Harbaugh, 1998; Andreoni and Petrie, 2004; Ariely et al., 2009; Lacetera and Macis; 2010; Karlan and McConnell, 2012; Gallus, 2017) or the impact of donor gifts or other private benefits linked to the contribution itself (e.g., Morgan and Sefton, 2000; Goeree et al., 2005; Landry et al., 2006; Carpenter et al., 2008; Elfenbein and McManus, 2010; Landry et al., 2012; Sieg and Zhang, 2012; Eckel et al., 2014; Kessler and Milkman, 2014).

To complement these unconditional insights, we estimate a series of linear regression models that explicitly control for observable and unobservable differences across potential donors. This analysis is important as such factors might systematically differ across treatment groups leading to erroneous inference from a simple analysis of the raw data. For our baseline specification, we restrict the sample to the years 2013 and 2014, and only include those individuals who registered for a PFD in both years. We estimate a linear regression model of the amount contributed for each individual that registered for the PFD online (including those who did not give) on indicator variables for our experimental treatments and other covariates: ${ }^{16}$

$$
D_{i j t}=\left(\beta_{1} \text { Others }_{j}+\beta_{2} \text { Self }_{j}\right) * 2014_{t}+2014_{t}+Z_{i}+\varepsilon_{i j t}
$$

where, $D_{i j t}$ is the contribution level of the $j^{\text {th }}$ individual in the $i^{\text {th }}$ zip code in year $t$, Others $s_{j}$ is an indicator for receiving the benefits to others message, $\operatorname{Sel} f_{j}$ is an indicator for receiving the benefits to self message, $2014_{t}$ is an indicator for the year 2014, and $Z_{i}$ are zip code fixed effects. Note that non-interacted indicators for treatment are captured by zip code fixed effects. As such, the estimated effect of receiving the benefits to others message is given by $\beta_{1}$ and the effect of receiving the benefits to self message is given by $\beta_{2}$. To account for unobservable heterogeneities at the zip code level, we cluster standard errors at the zip code level.

Empirical estimates presented in Model (1) of Table 4 provide additional support for the unconditional analysis, albeit with smaller magnitudes. Households in the benefits to self treatment contributed approximately $\$ 0.927$ more than did counterparts in the control group, a difference that is statistically significant at the $\mathrm{p}<0.001$ level. For perspective, this effect corresponds to a nearly $20 \%$ increase in average contributions. ${ }^{17}$ With 183,215 online filers in the benefits to self group, distributing this message raised an estimated $\$ 0.926 \times 183,215=\$ 169,657$. Had all online

\footnotetext{
${ }^{16}$ A fundamental assumption underlying the validity of our empirical strategy is the assumption that receipt of a given message did not impact the likelihood that the individual registers online. Table 3 provides support for this assumption. As noted in the table, filing methods were uncorrelated with the treatment assignment.

${ }^{17}$ From Panel B of Table 2, the average donation in 2014 made by individuals in the control group was $\$ 4.76$.
} 
filers in the state received this message, we estimate that Pick.Click.Give. would have raised an additional $\$ 0.926 \times 540,124=\$ 500,154$.

To gain insights into the factors that influence the decision of individuals to contribute through Pick.Click.Give., we estimate the linear probability of the contribution decision of households that registered for the FPD online by replacing donation amount with the binary decision of whether or not to give. Specifically, we replace $D_{i j}$ in our baseline estimation equation with a binary indicator equal to unity for people that made a donation.

Empirical estimates are presented in Table 5 and again indicate that messages that make salient self-interests influence the decision to donate. For example, we find that individuals residing in a zip that received the benefits to self message were roughly 0.2 percentage points (or approximately 4.5 percent) more likely to make a donation through Pick.Click.Give. than were counterparts in the control group - a difference that is statistically significant at the $p<0.05$ level.

A key identifying assumption for our baseline identification strategy is that there were no significant differences in pre-existing trends in rates of giving across treatment groups. To test these assumptions, and to provide a more nuanced and detailed description of the various treatment effects, we estimate a variant of our baseline estimation equation that interacts the two treatment indicators with year fixed effects:

$$
D_{i j t}=\sum_{t=2009}^{2015}\left(\beta_{1 t} \text { Others }_{j}+\beta_{2 t} \text { Self }_{j}\right) \text { Year }_{t}+Z_{i}+\text { Year }_{t}+\varepsilon_{i j t},
$$

where 2013 is the reference year and treatment effects are estimated for all other years 2009-2015. Zip code fixed effects are again given by $Z_{i}$ and year fixed effects by $Y_{e a r}$. For this specification, the effect of receiving the benefits to others postcard in year $t$ is given by $\beta_{1 t}$ and that for the benefits to self postcard is given by $\beta_{2 t}$. Successful randomization of treatments requires that there were no pre-existing trends such that $\beta_{1 t}=\beta_{2 t}=0$ for all years except 2014, the year of treatment (and possibly 2015 if treatment effects persisted over time). As with the baseline specification, errors are clustered at the zip code level and the panel is balanced.

The upper panel of Figure 7 gives the estimated treatment effects for the propensity to donate, and the lower panel gives the results for donation size. These results largely complement our baseline findings, and suggest that in 2014 subjects in the benefits to self treatment were approximately 0.2 percent points more likely to participate in Pick.Click.Give. and give roughly $\$ 1.00$ more than subjects in the control group. While this specification uncovers some pre-existing 
trend in in both the propensity to give and average donation size for the benefits to self group, for the two years immediately preceding treatment, trend is negligible.

Turning to the effects of messages highlighting benefits to others ("Make Alaska Better for Everyone"), we report a second result:

Result 2: The benefits to others message had the same positive impact on the likelihood of giving as the benefits to self message, but there was no effect on average donations relative to the control.

Heterogeneity in the response to our benefits to self and benefits to others treatments provides evidence that donors are responding to the content of our messages and not only the receipt of a message highlighting Pick.Click.Give. Importantly, this allows us to rule out models such as bounded rationality (Gabaix et al., 2006; Gabaix, 2014) or observation ("Hawthorne") effects (Levitt and List, 2007) as under any such model, the act of receiving a targeted message advertising Pick.Click.Give. should lead to increased donations. Hence, we would expect to observe treatment effects in both treatment groups.

Summary statistics in Table 2 suggest that both average contributions (\$5.21 versus \$4.72) and participation rates $(4.5 \%$ versus $4.4 \%)$ for individuals in our benefits to others treatment are statistically indistinguishable from those observed amongst counterparts in the control group (see also Figure 6). But comparing unconditional means can obscure important pre-existing differences in giving across treatments.

To complement these raw statistics, we return to the empirical estimates outlined in Tables 4 and 5 which present linear regression models exploring the impact of treatment on average contributions and underlying rates of giving, respectively. Model 1 of Table 4 shows that the average donation made in the benefits to others treatment was approximately $\$ 0.37$ more than that observed amongst counterparts in the control - a difference that is not statistically significant at any meaningful level. However, the approximate $\$ 0.56$ difference in average contributions relative to that observed in the benefits to self treatment is significant at the $p<0.10$ level. ${ }^{18}$

\footnotetext{
${ }^{18}$ Because differences in treatment effects are linear combinations of multiple parameter estimates from the baseline estimation equation, the delta method was used to construct confidence intervals (Stata post-estimation command lincom).
} 
Considering average participation rates, we find similar treatment effects across the two groups. As noted in Model 1 of Table 5, there is no discernable difference in the likelihood of giving across those in the benefits to self and benefits to others treatments, and people in both groups are more likely to contribute than those in the control.

These two findings are jointly explained by larger average donations being given by individuals in the benefits to self treatment. Model 1 of Table 6 shows that, conditional on participation in the charitable program, individuals in the benefits to self group gave $\$ 10.07$ more than subjects in the control group (significant at the $\mathrm{p}<.05$ level) and individuals in the benefits to others group behaved statistically no differently than those in the control group. Figure 8 was constructed similar to Figure 7, and reinforces these findings. Conditional on giving, subjects in the benefits to self group made larger donations and that this effect was only significant in the year of treatment, 2014.

Taken together, our first two results provide evidence that targeted messages and normative appeals can influence donor behavior. However, the efficacy of such appeals depends upon the way in which the benefits of giving are framed; donors are more motivated by appeals that highlight self-benefits than those that highlight how giving benefits others. Such differences are consistent with findings from the marketing literature showing the superiority of self-benefit appeals to give when the choice is made in private or in environments with low observability (White and Peloza, 2009). Moreover, our findings share similarity with prior work using tests of crowd-out to identify the relative importance of impure altruism or warm-glow versus altruism and concerns for the well-being of others (e.g,. Kingma, 1989; Andreoni, 1993; Payne, 1998; Andreoni and Payne, 2003, 2011; Eckel et al., 2005; Crumpler and Grossman, 2008; Andreoni et al., 2014; Ottoni-Wilhelm et al., 2017). As in this prior work, donors in our experiment appear to be motivated more by self-benefit concerns than the well-being of others.

\section{Exploring Heterogeneity across Donor Types}

Our analysis thus far has examined behavior pooled across all donor types. However, as noted in Landry et al. (2010) there are important differences in behavior across warm- and coldlist households - prior donors are more likely to give and are less responsive to both conditional and unconditional gifts. As we observe donations made through Pick.Click.Give. in 2013, our data are sufficiently rich to allow us to explore heterogeneity across different donor types. To do so, we 
augment our baseline regression models in Tables 4 and 5 to include an indicator variable for any individual who made a contribution in 2013. Rather than interacting this variable with the treatment and year indicators (which would require a triple interaction term), we re-estimate our baseline equations restricting the data set to cold-list (Model 5) and then warm-list (Model 6) donors. Results for these models suggest a third set of results:

Result 3a: Prior donors are more likely to give and provide larger average gifts than prospective donors.

Result 3b: Prospective donors in the benefits to self ("Warm Your Heart") treatment are more likely to give and provide larger gifts than counterparts in the control and benefits to others ("Make Alaska Better") group.

Support for Result $3 a$ is provided in Model 2 of Tables 4 and 5. As noted in Table 4, average donations for warm-list individuals are approximately $\$ 93.75$ greater than that for a prospective donor. As noted in Table 5, much of this difference is explained by dramatic differences in participation rates. Whereas less than $2 \%$ of prospective donors give through Pick.Click.Give. (see Panel B of Table 2), two-thirds of all warm-list individuals elect to give.

Support for Result $3 b$ is also provided in Tables 4 and 5. For example, as noted in Model 5 of Table 4, prospective ("Cold") donors in the benefits to self treatment provide average gifts that are approximately $\$ 0.646(44.5 \%)$ greater than those prospective donors observed in the control group. For prior donors, the relative effect of the benefits to self message is less pronounced - such types provide average gifts that are approximately $9.8 \%$ greater than a warm-list counterpart in the control group. ${ }^{19}$ Importantly, both of these differences are statistically significant at conventional levels.

We observe similar data patterns when exploring participation rates. As noted in Model 5 of Table 5, prospective donors in the benefits to self treatment are 0.43 percentage points (roughly $25 \%$ ) more likely to give than a prospective donor in the control group - a difference that is statistically significant at the $\mathrm{p}<0.01$ level. For prior donors (Model 6), the relative impact is again less pronounced. There is an approximate $5.4 \%$ increase in the likelihood of giving for a warm-list individual in the benefits to self treatment.

\footnotetext{
${ }^{19}$ From Table 4 Model 3 note that warm-list individuals that received the benefits to self postcard on average give $\$ 7.93$ more than warm-list individuals in control zip codes. This amounts to a $7.93 / 80.55=9.8 \%$ increase in the average donation size.
} 
Figure 9 presents the estimated treatment effects by year (the second estimation equation) for subjects that did and did not participate in Pick.Click.Give. at any point between 2009 and 2013. The upper panel shows that, for warm-list donors that gave at least once between 2009 and 2013, both treatments similarly increased the probability of donating. However, for subjects that had never before participated in Pick.Click.Give., we see that only the benefits to self postcard increased the probability of participating. These results are complemented by those reported for donation size in Figure 10. For previous donors, we see that both treatment groups gave larger average donations than the control, but this result is only significant for the benefits to self group. We again see that, for individuals that had not previously participated in the program, receiving the benefits to self message increased the average donation size and that receiving the benefits to others message had no effect.

Taken jointly, these differences suggest an interesting asymmetry. Whereas the benefits to self message impacted both prospective and prior donors, the effects - on both the propensity to donate and average donation size - were largest for people that did not previously participate in Pick.Click.Give.

A final result of interest concerns the impact of age and gender on donor behavior. As noted in List (2004), there are marked differences in generosity across men and women - particularly when exploring the behavior of young men. As we observe data on the age and gender of every individual in our data, we can explore similar patterns. To do so, we augment our baseline specifications to include indicators for women, those 50 and older, and those under the age of 18. As noted in Model 3 of Table 4, women and those age 50 or older provided larger average gifts than do other donor types. Moreover, average contributions for those under the age of 18 are significantly lower than those 50 and over. We observe similar differences along the extensive margin. As noted in Model 3 of Table 5, women and those age 50 or older were more likely to give than were other donor types, while those under the age of 18 were less likely to give.

Given that prior donors were more likely to give and provided larger average gifts than others, one may be concerned that these demographic effects are capturing differences in the likelihood an individual had given in the past. To rule out such possibility, we augment our regression to include controls for past donors along with our indicators for age and gender. Results from such specifications are included in column 4 of Tables 4 and 5. Conditional on past donations, women and those aged 50 or older were more likely to give than other types, while those under 
the age of 18 were less likely to give. However, whereas before women were more likely to give larger gifts, conditional on past donations, we see that they give smaller average gifts.

Interestingly, the observed gender differences are consistent with findings in Della Vigna et al. (2013) who find differences in the distribution for altruism across men and women. In our setting, women were more likely to give and provided larger average gifts. However, conditioned on giving, it was men who provided more generous gifts. Taken jointly, this suggests that the distribution of altruism for women was less disperse than the distribution for men; the precise pattern identified by the structural estimates in Della Vigna et al. (2013).

\section{Robustness Checks}

Recall that our randomization occurred at the zip code level. While we balanced on observables, there may be unobserved differences across zip codes that could impact rates of giving independent of treatment. For example, during the 2014 campaign, Pick.Click.Give. sponsored a media campaign, particularly in the three largest markets in the state - Anchorage, Juneau and Fairbanks, that used television and radio ads encouraging individuals to donate through Pick.Click.Give. Unfortunately, we do not observe the timing or content of such advertisements and thus are unable to directly control for any such efforts. Similarly, larger charities such as Bean's Café and United Way of Anchorage conducted their own marketing campaigns targeting potential donors.

As a first set of robustness checks, we augment our baseline specifications by restricting our sample to zip codes in Anchorage, Fairbanks, and Juneau and re-estimate our baseline set of equations. Given the previous advertising campaigns delivered to these markets, this sub-sample of individuals is more likely to be aware of the Pick.Click.Give. program. If treatment effects simply reflect learning about the existence of Pick.Click.Give., then we may expect to find negligent treatment effects for this specification. Table A2 shows that the effect of receiving either message was smaller than before, but remains statistically significant for the benefits to self message. Table A3 reinforces the idea that, within the three major Alaskan markets, only the benefits to self message effectively increased the propensity to give.

Our data includes both the home and mailing zips for every individual in our sample. For most individuals, the home and mailing zips matched. However, for approximately 172,614 (18\%) of our 2013-2014 sample, the home and mailing zip codes do not match. For such individuals, it 
is uncertain whether they would have received our treatment postcards and if they did receive a postcard which postcard they would observe. As a third robustness check on our results, we thus restrict the sample to the subset of individuals for whom the home and mailing zips matched and re-estimate our models of interest.

Results for this robustness check are contained in Tables A4 and A5 of the appendix. Importantly, all three of our main results are unaffected if we restrict the sample to those with matching home and mailing zips. Those receiving the benefits to self message are more likely to provide larger average gifts than do counterparts in the control and benefits to others treatment. In contrast, the average donation of those receiving the benefits to others postcard is no different from that observed amongst counterparts in the control group. Though we again see that individuals in both treatment groups were equally as likely to make a donation, and more likely to give a donation than those individuals in the control group.

A number of individuals also receive mail to a P.O. Box and so may have received a post card with a lag, or may not have received it at all. Thus, we also exclude from the analysis individuals whose mailing address is a P.O. Box and run our empirical models on the resulting subsample of 389,501 individuals. Results for this robustness check are contained in Tables A6 and A7 of the appendix and are consonant with results from our main specifications. Those receiving the benefits to self message were approximately 0.25 percentage points (about $5.3 \%$ ) more likely to make a donation and provided average donations that were about $\$ 1.07$ (approximately 22\%) greater than counterparts in the control. We again find that, while the propensity to give was similarly affected by the two treatments, the benefits to self message was more effective at increasing the average donation.

As a final robustness check and plausible placebo test, we restrict our sample to those individuals whose physical zip codes did not match their mailing zip codes in the year of the treatment, 2014. Because some people with mis-matching zip codes may have still received a mailer, we anticipate that this restriction in the data will not significantly affect estimated treatment effects but may inflate the associated standard errors. These results are given in Tables A8 and A9 in the appendix and show that, while the point estimates are similar to before, treatment effects mostly are not significant, as expected. 
Taken jointly, these robustness checks give us confidence that we are capturing a response to our targeted messages rather than some unobserved heterogeneity across zips or rural areas that may not have been familiar with Pick.Click.Give. prior to postcards being sent out.

\section{Do Treatment Effects Persist?}

There is a growing body of work showing that behavioral interventions tend to wane over time (e.g., Gneezy and List, 2006; Landry et al., 2010; Ferraro and Price, 2013; Allcott and Rogers, 2014). Given this body of work, it is important to explore whether the effects of our targeted messages are sustained across campaigns and impact long-run patterns of giving. To better ascertain the long-run impacts of our different messages, we use data on treatment assignment in 2014 and examine whether this impacts contributions through Pick.Click.Give. during the 2015 campaign. As with the original experiment, we restrict the sample to those individuals who registered for the Permanent Fund Dividend online and were thus provided the opportunity to given through Pick.Click.Give.

Exploring differences across those who received the benefits to self message in 2014 and those in our control group, we see the first evidence that treatment effects may persist. Figure 7 shows that, relative to counterparts that did not receive a message in 2014 , those that received the benefits to self message were approximately 0.28 percentage points $(4.2 \%)$ more likely to donate in 2015 than individuals that did not receive a message. Similarly, average donations in 2015 for those in our benefits to self group were about $\$ 1.05$ (14.7\%) greater than those who did not receive a message during the 2014 campaign. We observe similar differences if we compare the contribution decisions of those originally assigned to our benefits to self treatment with counterparts originally assigned to the benefits to others treatment.

Separating the data according to previous participation in Pick.Click.Give., the effect of the benefits to self message shows signs of persistence for both previous donors (people who gave at least once between 2009 and 2013), and especially for those who had never participated in Pick.Click.Give. before. For the latter group, subjects that received the benefits to self message were 0.5 percentage points (18.5\%) more likely to give in 2015. Similarly, from the lower panel of Figure 4 we see that in 2015, subjects that received the benefits to self message gave $\$ 0.67$ (35.7\%) more on average than subjects in the control. Taken together, these results suggest the effect of the benefits to self message is persistent, especially for first time givers. Yet, as in past 
work (e.g., Ferraro and Price, 2013; Allcott and Rogers, 2014; Bernedo et al., 2014) the effectiveness of the benefits to others "nudge" waned over time; subjects in this treatment group behaved no differently than those in the control group in 2015 .

\section{Conclusions}

A growing body of literature sets forth to explore the economics of charity and the relationship between fundraisers and potential donors. Much of this work has focused on measuring the effectiveness of different fundraising techniques such as charitable lotteries or matching gifts that change the relative costs of benefits of giving. Our study extends this literature by exploring the effect of targeted messages and normative appeals on donor behavior.

To do so, we designed a natural field experiment in conjunction with the state of Alaska's Pick.Click.Give. program. As part of the 2014 marketing campaign, we randomly allocated the approximate 290,000 households in the state into either a control group or one of two treatment groups that received a postcard that included a slogan to highlight either benefits to self ("Warm your heart") or benefits to others ("Make Alaska better for everyone"). The slogans were designed to reflect the two main motives for charitable giving - concerns for the benefits to self (impure altruism or "warm-glow") or concerns for the well-being of others (pure altruism) - and provide a way to disentangle the relative importance of each.

Results from our experiment highlight the relative importance of benefits to self as a driver of giving. Individuals who received the benefits to self message were approximately 4.5 percent more likely to give than counterparts in the control group and tend to support more charitable organizations. Moreover, average contributions in the benefits to self treatment were approximately 20 percent greater than those in our baseline. Messages that highlight the benefits to others, in contrast, had a similar impact on the likelihood of giving but had no impact on average donations. Interestingly, these same data patterns are observed for both warm-list households who gave through Pick.Click.Give. in 2013 and cold-list counterparts who did give in the prior year's campaign - although the effects are more pronounced amongst cold-list households.

For academics, our results are noteworthy in that they provide a deeper understanding of individual behavior and what drives the private provision of public goods. Importantly, our findings suggest that giving is motivated by self-interests rather than concerns for charitable output per se. That said, we cannot rule out alternative explanations such as the identifiable victim effect 
and motivational crowding that arises when one perceives the efficacy of their donation to be low for the relative inefficacy of the "Make Alaska Better" message. Future work should explore this possibility and identify why the benefits to others message had smaller effects on overall patterns of giving.

Our results are also noteworthy in that the distribution of gifts across cause types is fundamentally different than the distribution of gifts across cause types nationwide. While religious and education based causes receive the largest fraction of donations nationwide, the most popular cause types in our data are human services and animals and the environment - each of which receive more than 20 percent of all dollars. In part this can be explained by differences in the composition of charities included in Pick.Click.Give. and the composition of charities nationwide. Yet, the differences could also reflect the absence of fund-raising efforts and direct asks in our experiment. Given past work highlighting the importance of social pressures and the ask on donor behavior, future work should explore whether active solicitations influence the types of causes donors select and the allocation of funds across organizations.

For practitioners, our results are noteworthy in that they suggest ways to increase giving using simple messages that appeal to the donor's self-interests and the good feelings triggered by the act of giving. These findings are of particular interest to nonprofits in the state of Alaska and the design of the Pick.Click.Give. program which was established to increase overall giving statewide. If we had sent the benefits to self message to all households in the state, aggregate contributions would have increased by more than $\$ 500,000$.

Yet, the charitable marketplace is comprised of numerous nonprofits that compete for donations from a finite number of budget constrained agents. In such an environment, changes in giving through Pick.Click.Give. could impact aggregate patterns of giving. Future work should explore whether the dollars attracted via our appeal represent an increase in aggregate giving or simply a substitution of funds across charities and/or time. 


\section{References}

Allcott, H. \& Greenstone, M. (2017). "Measuring the Welfare Efects of Residential Energy Efficiency Programs," the National Bureau of Economic Research, Working Paper No. 23386.

Allcott, H. \& Rogers, T. (2014). “The Short-Run and Long-Run Effects of Behavioral Interventions: Experimental Evidence from Energy Conservation," American Economic Review, 104(10), 3003-3037.

Allcott, H. (2011). "Social Norms and Energy Conservation," Journal of Public Economics, 95(9-10), 1082-1095.

Alpizar, F., Carlsson, F., \& Johansson-Stenman, O. (2008). "Anonymity, Reciprocity, and Conformity: Evidence from Voluntary Contributions to a National Park in Costa Rica," Journal of Public Economics, 92(5-6), 1047-1060.

Altmann, S., Falk, A., Heidhues, P., Jayaraman, R., and Teirlinck, M. (2019). "Defaults and Donations: Evidence from a Field Experiment," Review of Economics and Statistics, 101(5), 1-18.

Andreoni, J. (1989). "Giving with Impure Altruism: Applications to Charity and Ricardian Equivalence." Journal of Political Economy, 97, 1447-58.

Andreoni, J. (1990). "Impure Altruism and Donations to Public Goods: A Theory of WarmGlow Giving." The Economic Journal, 100(401), 464-477.

Andreoni, J. (1993). "An Experimental Test of the Public-Goods Crowding-Out Hypothesis." American Economic Review, 83(5), 1317-1327.

Andreoni, J. (1995). "Warm-Glow versus Cold-Prickle: The Effects of Positive and Negative Framing on Cooperation in Experiments," Quarterly Journal of Economics, 110(1), 1-21.

Andreoni, J. (1998). "Toward a Theory of Charitable Fund-Raising." Journal of Political Economy, 106(6), 1186-1213.

Andreoni, J., \& Payne, A. A. (2003). "Do Government Grants to Private Charities Crowd Out Giving or Fund-raising?." American Economic Review, 93(3): 792-812.

Andreoni, J. \& Petrie, R. (2004). "Public Goods Experiments Without Confidentiality: A Glimpse Into Fund-Raising,” Journal of Public Economics, 88(7-8), 1605-1623.

Andreoni, J., \& Payne, A. A. (2011). "Is Crowding Out Due Entirely to Fundraising? Evidence from a Panel of Charities." Journal of Public Economics, 95, 334-343. 
Andreoni, J., Payne, A. A., \& Smith, S. (2014). "Do grants to charities crowd out other income? Evidence from the UK." Journal of Public Economics, 114, 75-86.

Andreoni, J., Rao, J., \& Trachtman, H. (2017). "Avoiding the Ask: A Field Experiment on Altruism, Empathy, and Charitable Giving," Journal of Political Economy, 125(3), 625653.

Andreoni, J. and Serra-Garcia, M. (2016). “Time Inconsistent Charitable Giving,” NBER Working Paper \#22824.

Ariely, D., Bracha, A. \& Meier, St. (2009). "Doing Good or Doing Well? Image Motivation and Monetary Incentives in Behaving Prosocially." American Economic Review, 99(1), 54455.

Baek, T.H., Yoon, S., Kim, S., and Kim, Y. (2019). "Social Exclusion Influences on the Effectiveness of Altruistic Versus Egoistic Appeals in Charitable Advertising," Marketing Letters, 30, 75-90.

Benjamin, D. T., Choi, J. J. \& Strickland, A. J. (2010). "Social Identity and Preferences." American Economic Review, 100(4), 1913-1928.

Bernedo, M., Ferraro, P., Price, M. (2014). “The Persistent Impacts of Norm-Based Messaging and Their Implications for Water Conservation," Journal of Consumer Policy, 37(3), 437-452.

Beshears, J., Choi, J., Baibson, D. Madrian, B., \& Milman, K. (2015), “The Effect of Providing Peer Information on Retirement Savings Decisions," The Journal of Finance, 70(3), 1161-1201.

Bracha, A., Menietti, M., \& Vesterlund, L. (2011). "Seeds to Succeed? Sequential Giving to Public Projects.” Journal of Public Economics, 95(5-6), 416-427.

Breman, A. (2011). "Give More Tomorrow: Two Field Experiments on Altruism and Intertemporal Choice," Journal of Public Economics, 95(11-12), 1349-1357.

Brent, D., Cook, J., \& Olsen, S. (2015). "Social Comparisons, Household Water Use, and Participation in Utility Conservation Programs: Evidence from Three Randomized Trials," Journal of the Association of Environmental and Resource Economists, 2(4), 597-627. 
Brunel, Frederic and Nelson, M. (2000). "Explaining Gendered Responses to "Help-Self” and "Help-Others" Charity Ad Appeals: The Mediating Role of World-Views," Journal of Advertising, 29(3), 15-28.

Carpenter, J., Holmes, J., \& Matthews, P. (2008). "Charity auctions: a field experiment." The Economic Journal, 118(525), 92-113.

Castillo, M., Petrie, R., \& Wardell, C. (2014). "Fundraising Through Online Social Networks: A Field Experiment on Peer-to-Peer Solicitation, ” Journal of Public Economics, 114, 2935.

Chen, Yan, Xin Li, and Jeffrey K. Mackie-Mason. (2006). "Online Fundraising Mechanisms: A Field Experiment." Contributions to Economic Analysis and Policy, 5(2), Article 4.

Chen, Y., Harper, F. M., Konstan, J., \& Xin Li, S. (2010). "Social Comparisons and Contributions to Online Communities: A Field Experiment on MovieLens," American Economic Review, 100(4), 1358-98.

Chen, Y., Lu, F., \& Zhang, J. (2017). "Social Comparisons, Status, and Driving Behavior," Journal of Public Economics, 155, 11-20.

Costa, D. \& Kahn, M. (2013). "Energy Conservation "Nudges” and Environmentalist Ideology: Evidence from a Randomized Residential Electricity Field Experiment," Journal of the European Economic Association, 11(3), 680-702.

Crumpler, H. \& Grossman, Ph. J. (2008). "An Experimental Test of Warm Glow Giving," Journal of Public Economics, 92(5-6), 1011-1021.

DellaVigna, S., List, J. A., \& Malmendier, U. (2012). "Testing for Altruism and Social Pressure in Charitable Giving." Quarterly Journal of Economics, 127(1), 156.

DellaVigna, S., List, J., Malmendier, U., \& Roa, G. (2013). “The Importance of Being Marginal: Gender Differences in Generosity," American Economic Review, 103(3), 686-590.

Eckel, C. \& Grossman, Ph. J. (2006). "Subsidizing Charitable Giving with Rebates or Matching: Further Laboratory Evidence.” Southern Economic Journal, 72 (4), 794-807.

Eckel, C., Grossman, Ph. J., \& Johnston, R. (2005). “An Experimental Test of the Crowding Out Hypothesis.” Journal of Public Economics, 89(8), 1543-1560.

Eckel, C., Herberich, D., \& Meer, J. (2014). "A Field Experiment on Directed Giving at a Public University." NBER Working Papers, No. 20180. 
Elfenbein, D. W. \& McManus, B. (2010). “A Greater Price for a Greater Good? Evidence that Consumers Pay More for Charity-Linked Products." American Economic Journal: Economic Policy, 2(2), 28-60.

Evans, W. \& Moore, T. (2011). "The Short-term Mortality Consequences of Income Receipt," Journal of Public Economics, 95(11-12), 1410-1424.

Falk, A. (2007). "Gift Exchange in the Field." Econometrica, 75(5), 1501-1511.

Feiler, D., Tost, L., and Grant, A. (2012). "Mixed Reasons, Missed Givings: The Costs of Blending Egoistic and Altruistic Reasons in Donation Requests," Journal of Experimental Social Psychology, 48, 1322-1328.

Fellner, G., Sausgruber, R., \& Traxler, C. (2013). "Testing Enforcement Strategies in the Field: Threat, Moral Appeal and Social Information," Journal of the European Economic Association, 11(3), 634-660.

Ferraro, P. \& Price, M. (2013). “Using Nonpecuniary Strategies to Influence Behavior: Evidence from a Large-Scale Field Experiment," The Review of Economics and Statistics, 95(1), 64-73.

Fisher, R., Vandenbosch, M., \& Antia, K. (2008). “An Empathy-Helping Perspective on Consumers' Responses to Fund-Raising Appeals," Journal of Consumer Research, 35(3), $519-531$.

Frey, B. S. \& Meier, S. (2004). "Social Comparisons and Pro-social Behavior: Testing "Conditional Cooperation" in a Field Experiment," American Economic Review, 94(5), 1717-1722.

Gabaix, X. \&Laibson, D. (2006). "Shrouded Attributes, Consumer Myopia, and Information Suppression in Competitive Markets," The Quarterly Journal of Economics, 121(2),505540.

Gabaix, X. (2014). “A Sparsity-Based Model of Bounded Rationality,” The Quarterly Journal of Economics, 129(4), 1661-1710.

Gallus, J. (2017). "Fostering Public Good Contributions with Symbolic Awards: A Large-Scale Natural Field Experiment at Wikipedia," Management Science, 63(12), 3999-4446.

Gneezy, U. \& List, J. (2006). "Putting Behavioral Economics to Work: Testing for Gift Exchange in Labor Markets Using Field Experiments," Econometrica, 74(5), 1365-1384. 
Goeree, J. K., Maasland, E., Onderstal, S. \& Turner, J. L. (2005). "How (Not) to Raise Money," Journal of Political Economy, 113(4), 897-926.

Goldsmith, S. (2010). “The Alaska Permanent Fund Dividend: A Case Study in Implementation of a Basic Income Guarantee," Institute of Social and Economic Research, University of Alaska Anchorage.

Goldstein N., Cialdini R., \& Griskevicius V. (2008). “A Room with a Viewpoint: Using Social Norms to Motivate Environmental Conservation in Hotels," Journal of Consumer Research, 35(3), 472-482.

Goswami, I. and Urminsky, O. (2016). "When Should the Ask Be a Nudge? The Effect of Default Amounts on Charitable Donations," Journal of Marketing Research, 53, 829846.

Hahn, R., Metcalfe, R., Novgorodsky, D., \& Price, M. (2016). “The Behavioralist as Policy Designer: The Need to Test Multiple Treatments to Meet Multiple Targets," the National Bureau of Economic Research, Working Paper No. 22886.

Hallsworth, M., List, J., Metcalfe, R., \& Vlaev, I. (2017). “The Behavioralist as Tax Collector: Using Natural Field Experiments to Enhance Tax Compliance," Journal of Public Economics, 148, 14-31.

Harbaugh, W. T. (1998). "What do Donations Buy? A Model of Philanthropy based on Prestige and Warm Glow." Journal of Public Economics, 67(2), 269-284.

Holladay, S., LaRiviere, J., Novgorodsky, D., \& Price, M. (2019). "Prices Versus Nudges: What Matters for Search Versus Purchase of Energy Investments?” Journal of Public Economics, 172, 151-173.

Hsieh, C. (2003). "Do Consumers React to Anticipated Income Changes? Evidence from the Alaska Permanent Fund." American Economic Review, 93(1): 397-405.

Huck, St. \& Rasul, I. (2011). "Matched fundraising: Evidence from a Natural Field Experiment." Journal of Public Economics, 95(5-6), 351-362.

Imas, A. (2014). "Working for the Warm Glow: On the Benefits and Limits of Prosocial Incentives," Journal of Public Economics, 114, 14-18.

Ito, K., Ida, T., \& Tanaka, M. (2018). "Moral Suasion and Economic Incentives: Field Experimental Evidence from Energy Demand," American Economic Journal: Economic Policy, 10(1), 240-267. 
Jones, D. \& Marinescu, I. (2018). The labor market impacts of universal and permanent cash Transfers: Evidence from the Alaska permanent fund (No. w24312). National Bureau of Economic Research.

Karlan, D., \& List, J .A. (2007). "Does Price Matter in Charitable Giving? Evidence from a Large-Scale Natural Field Experiment." American Economic Review, 97(5): 1774-1793.

Karlan, D. \& McConnell, M. (2012). "Hey Look at Me: The Effect of Giving Circles on Giving." NBER Working Papers, No. 177737.

Kessler, J. \& Milkman, K. L. (2014). “Identity in Charitable Giving.” Working Paper.

Kingma, B. R. (1989). "An Accurate Measurement of the Crowd-Out Effect, Income Effect, and Price Effect for Charitable Contributions," Journal of Political Economy, 97(5), 11971207.

Knutsson, M. Martinsson, P. \& Wollbrant, C. (2013). "Do People Avoid Opportunities to Donate? A Natural Field Experiment on Recycling and Charitable Giving.” Journal of Economic Behavior \& Organization, 93, 71-77.

Kueng, L. (2015). "Explaining Consumption Excess Sensitivity with Near-Rationality: Evidence from Large Predertermined Payments," the National Bureau of Economic Research, Working Paper No. 21772.

Kueng, Lorenz. (2018). "Excess Sensitivity of High-Income Consumers.” The Quarterly Journal of Economics, 133(4), 1693-1751.

Lacetera, N. \& Macis, M. (2010). "Social Image Concerns and Prosocial Behavior: Field Evidence from a Nonlinear Incentive Scheme." Journal of Economic Behavior \& Organization, 76(2), 225-237.

Landry, C. E., Lange, A., List, J., Price, M. K., \& Rupp, N. G. (2006). "Toward an Understanding of the Economics of Charity: Evidence from a Field Experiment." Quarterly Journal of Economics, 121(2), 747-782.

Landry, C. E., Lange, A., List, J. A., Price, M. K., \& Rupp, N. G. (2010). “Is a Donor in Hand Better than Two in the Bush? Evidence from a Natural Field Experiment," American Economic Review, 100 (2010): pp. 958-983.

Landry, C. E., Lange, A., List, J. A., Price, M. K., \& Rupp, N. G. (2012). “Using Donor Gifts to Drive Fundraising: Theory and Evidence from a Natural Field Experiment," Working Paper. 
Levitt, S. \& List, J. (2007). "What Do Laboratory Experiments Measuring Social Preferences Reveal About the Real World?" Journal of Economic Perpectives, 21(2), 153-174.

List, J. A. (2004). "Young, Selfish and Male: Field Evidence of Social Preferences." The Economic Journal, 114(492), 121-149.

List, J. A. (2011). "The Market for Charitable Giving." Journal of Economic Perspectives, $25(2), 157-80$.

List, J. A. \& Lucking-Reiley, D. (2002). "The Effects of Seed Money and Refunds on Charitable Giving: Experimental Evidence from a University Capital Campaign," Journal of Political Economy, 110(1), 215-233.

Meer, J. (2011). "Brother, Can You Spare a Dime: Peer Pressure in Charitable Solicitation." Journal of Public Economics. 95(7-8), 926-941.

Meier, St. (2007). "Do Subsidies Increase Charitable Giving in the Long Run? Matching Donations in a Field Experiment." Journal of the European Economic Association, $5(6), 1203-1222$.

Morgan, J. (2000). "Financing Public Goods by Means of Lotteries." Review of Economic Studies, 67(4), 761-784.

Morgan, J. \& Sefton, M. (2000). "Funding Public Goods with Lotteries: Experimental Evidence." Review of Economic Studies, 67(4), 785-810.

Nolan, J. M., Schultz, P. W., Cialdini, R. B., Goldstein, N. J., \& Griskevicius, V. (2008).

"Normative Social Influence is Underdetected," Personality and Social Psychology Bulletin, 34(7), 913-923.

Null, C. (2011). “Warm Glow, Information, and Inefficient Charitable Giving,” Journal of Public Economics, 95, 455-465.

Ottoni-Wilhelm, M., Vesterlund, L., \& Xie, H. (2017). "Why do People Give? Testing Pure and Impure Altruism," American Economic Review, 107(11), 3617-3613.

Payne, A. A. (1998). "Does the Government Crowd-out Private Donations? New Evidence from a Sample of Nonprofit Firms." Journal of Public Economics, 69(3), 323-345.

Potters, J., Sefton, M., \& Vesterlund, L. (2007). "Leading-by-example and Signaling in Voluntary Contribution Games: An Experimental Study.” Economic Theory, 33(1), 169182. 
Pruckner, G. \& Sausgruber, R. (2013). "Honesty on the Streets: A Field Study on Newspaper Purchasing," Journal of the European Economic Association, 11(3), 661-679.

Scharf, K. \& Smith, S. (2014). "The Price Elasticity of Charitable Giving: Does the Form of Tax Relief Matter?” International Tax and Public Finance, February 2014, 1-32.

Seira, E., Elizondo, A., \& Laguna-Muggenburg, E. (2017). “Are Information Disclosures Effective? Evidence from the Credit Card Market," American Economic Journal: Economic Policy, 9(1), 277-307.

Shang, J. \& Croson, R. (2009). "A Field Experiment in Charitable Contribution: The Impact of Social Information on the Voluntary Provision of Public Goods." The Economic Journal, 119(540), 1422-1439.

Sieg, H. \& Zhang, J., (2012). "The Importance of Managerial Capacity in Fundraising: Evidence from Land Conservation Charities," International Journal of Industrial Organization, 30(6), 724-734.

Singh, J., Teng, N., and Netessine, S. (2019). "Philanthropic Campaigns and Customer Behavior: Field Experiments on an Online Taxi Booking Platform," Management Science, 65(2), 913-932.

Smith, S., Windmeijer, F., \& Wright, E. (2013). "Peer Effects in Charitable Giving: Evidence from the (Running) Field," The Economic Journal, 125(585), 1053-1071.

Tonin, M. and Vlassopoulos, M. (2010). "Disentangling the Sources of Pro-Socially Motivated Effort: A Field Experiment," Journal of Public Economics, 94, 1086-1092.

Tonin, M. and Vlassopoulos, M. (2014). “An Experimental Investigation of Intrinsic Motivations for Giving," Theory and Decision, 76, 47-67.

Vesterlund, L. (2003). "The Informational Value of Sequential Fundraising." Journal of Public Economics, Vol. 87(3-4), 627-657.

Watson, B, Guettabi, M. \& Reimer, M. (2019). “Universal Cash and Crime.” Review of Economics and Statistics, 1-45.

White, K., \& Peloza, J. (2009). “Self-Benefit versus Other-Benefit Marketing Appeals: Their Effectiveness in Generating Charitable Support," Journal of Marketing, 73(4), 109-124. 
Figure 1: Permanent Fund Dividend Amounts (1982-2015)

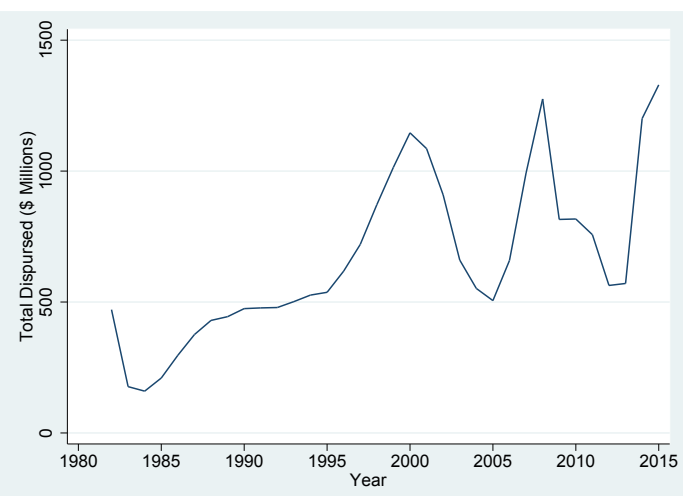

(a) Total Disbursement

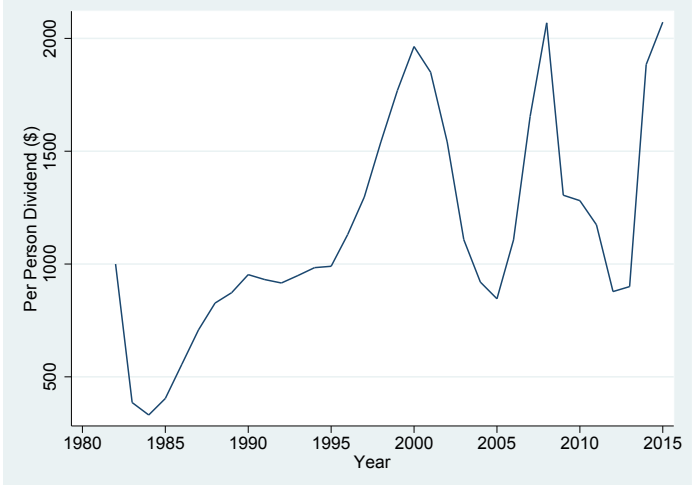

(b) Per Person Dividend

Note: Panel (a) gives information on total annual disbursements and panel (b) gives the per person dividend amount. Data provided by the Permanent Fund Division of the Alaska Department of Revenue.

Table 1: Historic Patterns of Giving to Pick.Click.Give

\begin{tabular}{ccc}
\hline \hline & \# of Donors & Total Dollars Contributed \\
\hline 2009 & 4,005 & $\$ 400,385$ \\
2010 & 7,657 & $\$ 697,099$ \\
2011 & 15,863 & $\$ 1,317,431$ \\
2012 & 20,436 & $\$ 1,991,565$ \\
2013 & 24,336 & $\$ 2,381,650$ \\
2014 & 26,610 & $\$ 3,132,583$ \\
2015 & 31,587 & $\$ 3,490,455$ \\
\hline
\end{tabular}

Note: Cell entries provide data on historic patterns of giving through the Pick.Click.Give program. Cell entries can be read as follows: in 2009 there were 4,005 donors who gave a combined $\$ 400,385$ to eligible nonprofits in the state. 
Figure 2: Treatment Postcard "Benefits to Others"

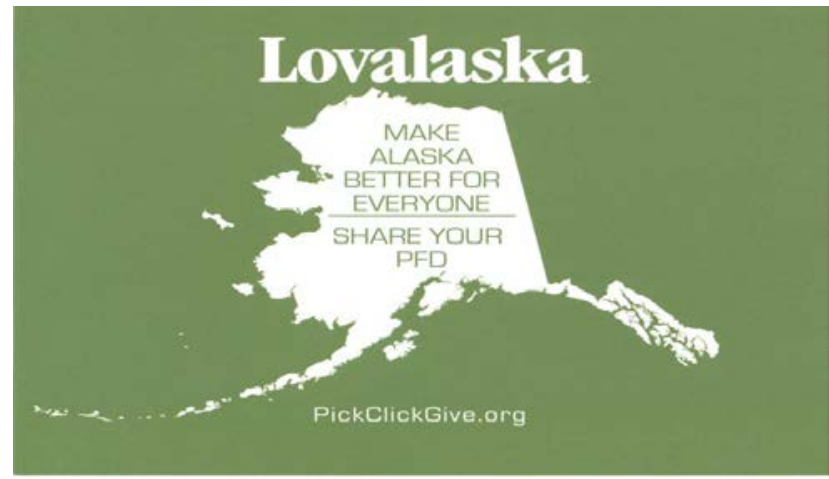

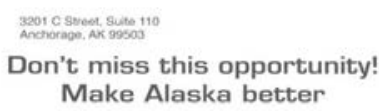
for everyone.

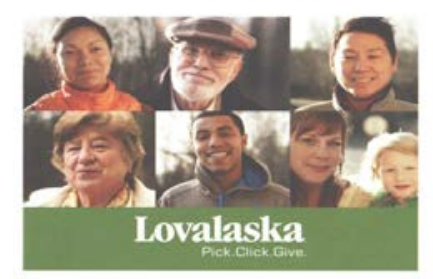

Note: The upper frame shows the front page and the lower frame the back page of the "Benefits to Others" postcard. Treatment letters were delivered as standard-sized postcards. Variation in framing is presented graphically on the front page and verbally on the back page. 
Figure 3: Treatment Postcard "Benefits to Self"

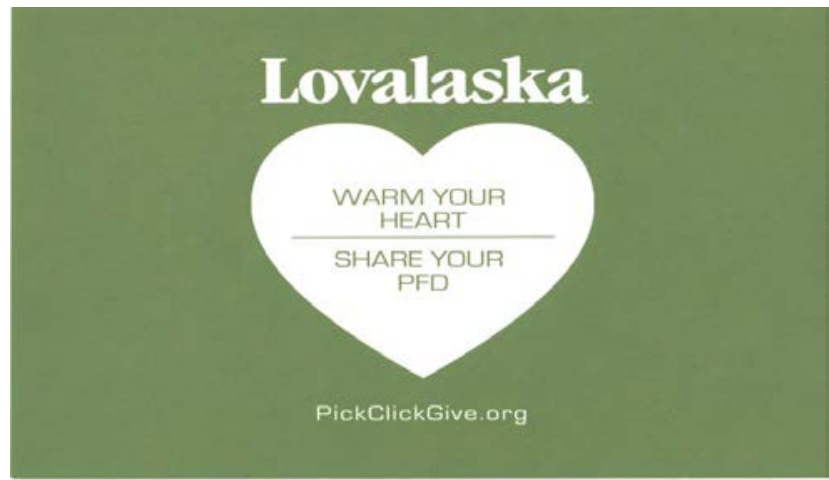

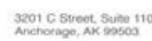

Don't miss this opportunity! Warm your heart.

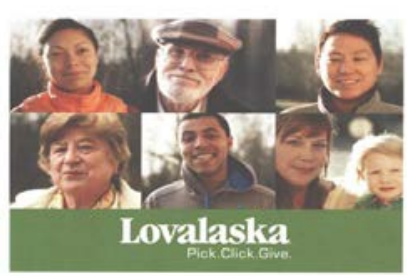

Note: The upper frame shows the front page and the lower frame the back page of the "Benefits to Self" postcard. Treatment letters were delivered as standard-sized postcards. Variation in framing is presented graphically on the front page and verbally on the back page. 
Figure 4: Geographic Overview of Experimental Population and Treatment Assignment

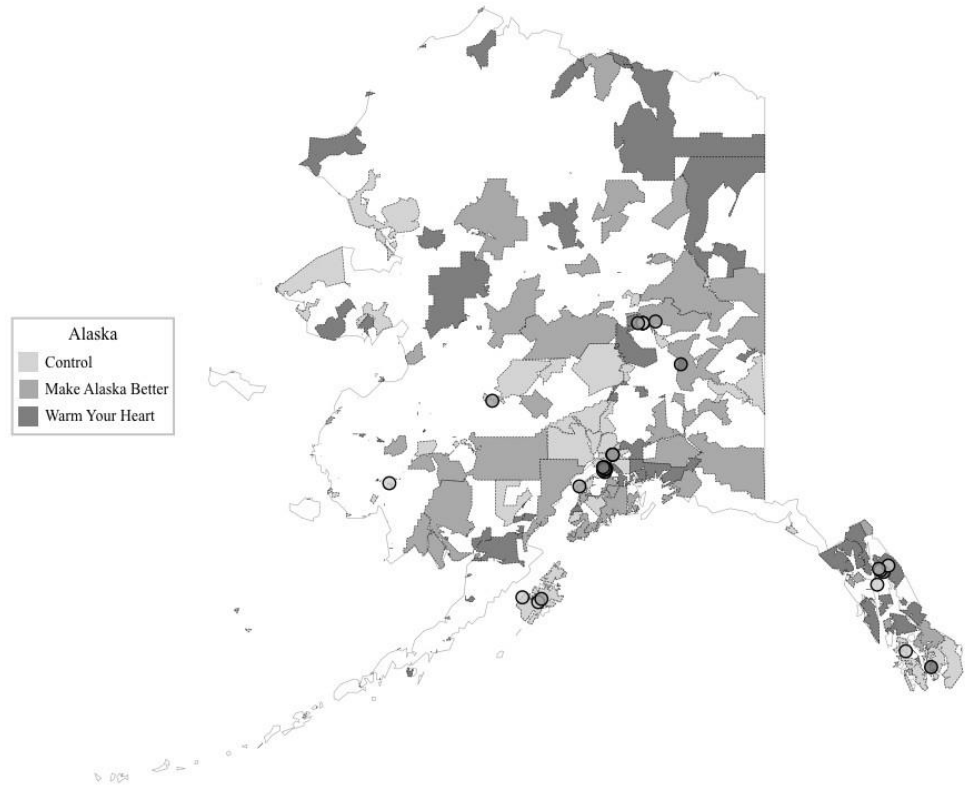

Note: Alaskan ZIP codes are shaded according to their random treatment assignment. Light gray represents control (C) ZIP codes, medium gray Make Alaska Better (Others) ZIP codes, and dark gray Warm Your Heart (Self) ZIP codes. White spaces are due to national parks or areas with very low population density, which were excluded from the randomization. Circles represent all $\mathrm{PO}$ boxes and their respective treatment assignment. 
Figure 5: Geographic Overview of Experimental Population and Treatment Assignment

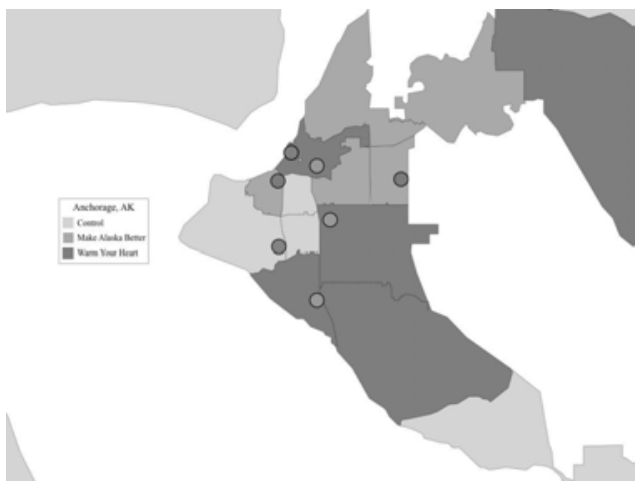

(a) Anchorage

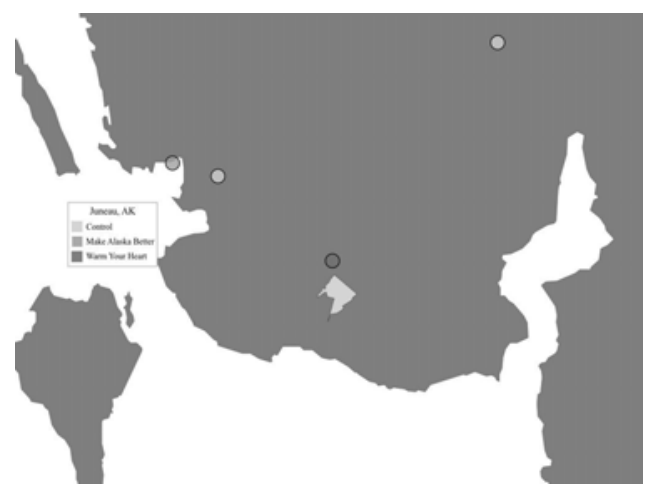

(c) Juneau

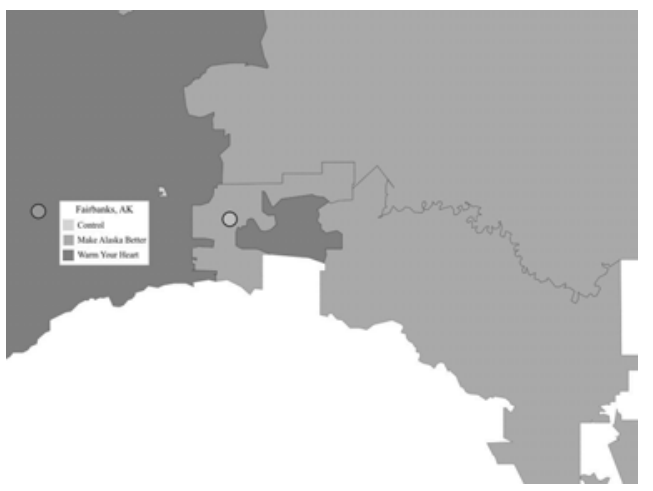

(b) Fairbanks

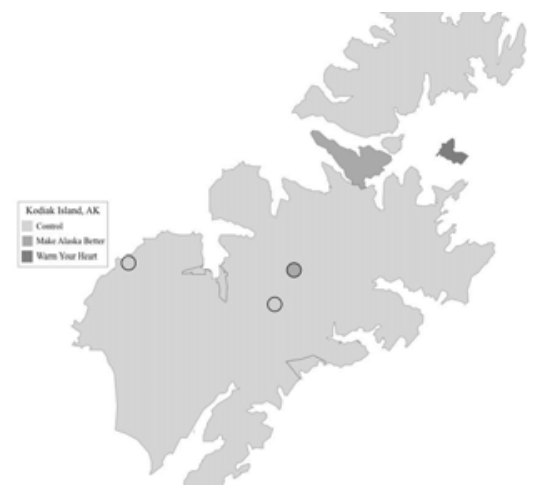

(d) Kokiak

Note: Alaska's main metropolitan area ZIP codes are shaded according to their random treatment assign- ment. Light gray represents control (C) ZIP codes, medium gray Make Alaska Better (MAB) ZIP codes, and dark gray Warm Your Heart (WYH) ZIP codes. White spaces are due to national parks or areas with very low population density, which were excluded from the randomization. Circles represent PO boxes and their respective treatment assignment. 
Table 2: Summary Statistics for 2014 Treatment Assignment

\begin{tabular}{lccc}
\hline \hline & Control & Others & Self \\
\hline Panel A: 2013 & \multicolumn{3}{c}{} \\
\hline Individuals & 152,916 & 165,377 & 164,871 \\
Donors & 7,103 & 7,589 & 9,644 \\
Donation Rate & 0.046 & 0.045 & 0.058 \\
Total Donations & 648,475 & 733,300 & 999,875 \\
Average Donation & 4.240 & 4.434 & 6.064 \\
\hline Panel B: 2014 [Year of Treatment] & \multicolumn{3}{c}{} \\
\hline Individuals & 169,441 & 187,468 & 183,215 \\
Donors & 7,552 & 8,498 & 10,560 \\
Donation Rate & 0.044 & 0.045 & 0.057 \\
Donation Rate (Warm-list) & 0.668 & 0.685 & .704 \\
Donation Rate (Cold List) & 0.017 & 0.018 & 0.021 \\
Total Donations & 807,548 & 976,725 & $1,348,310$ \\
Average Donation & 4.766 & 5.210 & 7.359 \\
Average Donation (Warm-list) & 80.555 & 91.429 & 100.871 \\
Average Donation (Cold-list) & 1.449 & 1.572 & 2.163 \\
Zip Codes & 89 & 90 & 89 \\
\hline Panel C: 2015 & \multicolumn{3}{c}{} \\
\hline Individuals & 154,169 & 167,359 & 166,441 \\
Donors & 9,304 & 9,985 & 12,298 \\
Donation Rate & 0.060 & .059 & 0.073 \\
Total Donations & 941,137 & $1,084,536$ & $1,464,782$ \\
Average Donation & 6.104 & 6.480 & 8.800 \\
\hline
\end{tabular}

Note: Summary statistics are presented for campaign years 2013 (Panel A), 2014 (Panel B), and 2015 (Panel C). All cell entries are based on the random assignment of the 2014 campaign. Treatment postcards were only delivered in 2014. Statistics are for online filers only.

Table 3: Means Tests

\begin{tabular}{lcccccc}
\hline \hline & $(1)$ & $(2)$ & $(3)$ & \multicolumn{3}{c}{$p$-value } \\
& Control & Others & Self & $(1):(2)$ & $(1):(3)$ & $(2):(3)$ \\
\hline Propensity to Donate & 0.044 & 0.045 & 0.057 & 0.871 & 0.002 & 0.008 \\
& $(.003)$ & $(.004)$ & $(.004)$ & & & \\
Average Donation & 4.765 & 5.209 & 7.358 & 0.612 & 0.001 & 0.028 \\
& $(.461)$ & $(.874)$ & $(.780)$ & & & \\
Registered Online & 0.823 & 0.815 & 0.843 & 0.767 & 0.487 & 0.241 \\
& $(.022)$ & $(.026)$ & $(.029)$ & & & \\
\hline Note: Cell entries in columns 1-3 provide variable means in 2014. "Registered Online" is the share of
\end{tabular}
作 $p$-values of two-sample $t$-tests comparing different treatment groups in the last three columns. Standard errors are clustered at the zip code level. 
Table 4: Donation: 2013-2014

\begin{tabular}{|c|c|c|c|c|c|c|}
\hline & \multicolumn{4}{|c|}{ Full Data } & \multirow{2}{*}{$\frac{\text { Cold List }}{(5)}$} & \multirow{2}{*}{$\frac{\text { Warm List }}{(6)}$} \\
\hline & (1) & $(2)$ & $(3)$ & $(4)$ & & \\
\hline \multirow[t]{2}{*}{2014} & .7795 & .7795 & .7066 & .7436 & 1.340 & -10.740 \\
\hline & $(.1844)$ & $(.1844)$ & $(.1836)$ & $(.1838)$ & $(.1181)$ & $(2.593)$ \\
\hline \multirow[t]{2}{*}{ Others $\times 2014$} & .3684 & .3684 & .3737 & .3710 & .1124 & 5.542 \\
\hline & $(.2910)$ & $(.2910)$ & $(.2911)$ & $(.2911)$ & $(.1973)$ & $(3.543)$ \\
\hline \multirow[t]{2}{*}{ Self $\times 2014$} & .9267 & .9267 & .9221 & .9244 & .6459 & 7.933 \\
\hline & $(.2769)$ & $(.2769)$ & $(.2762)$ & $(.2765)$ & $(.1989)$ & $(3.096)$ \\
\hline \multirow[t]{2}{*}{ Donor 2013} & & 93.749 & & 93.219 & & \\
\hline & & $(3.147)$ & & $(3.132)$ & & \\
\hline \multirow[t]{2}{*}{ Female } & & & 2.131 & -.2404 & & \\
\hline & & & $(.1230)$ & $(.1010)$ & & \\
\hline \multirow[t]{2}{*}{ Under 18} & & & -3.612 & -1.211 & & \\
\hline & & & $(.3074)$ & $(.1360)$ & & \\
\hline \multirow[t]{2}{*}{ Over 49} & & & 4.942 & 2.436 & & \\
\hline & & & $(.3447)$ & $(.2586)$ & & \\
\hline \multirow[t]{2}{*}{$($ Self-Others $) \times 2014$} & .5583 & .5583 & .5483 & .5534 & .5335 & 2.390 \\
\hline & $(.3056)$ & $(.3056)$ & $(.3050)$ & $(.3053)$ & $(.2249)$ & $(2.949)$ \\
\hline$R^{2}$ & .004 & .189 & .009 & .190 & .003 & .018 \\
\hline$N$ & 966,328 & 966,328 & 966,328 & 966,328 & 917,656 & 48,672 \\
\hline
\end{tabular}

Figure 6: Average Donation and \& Propensity to Donate

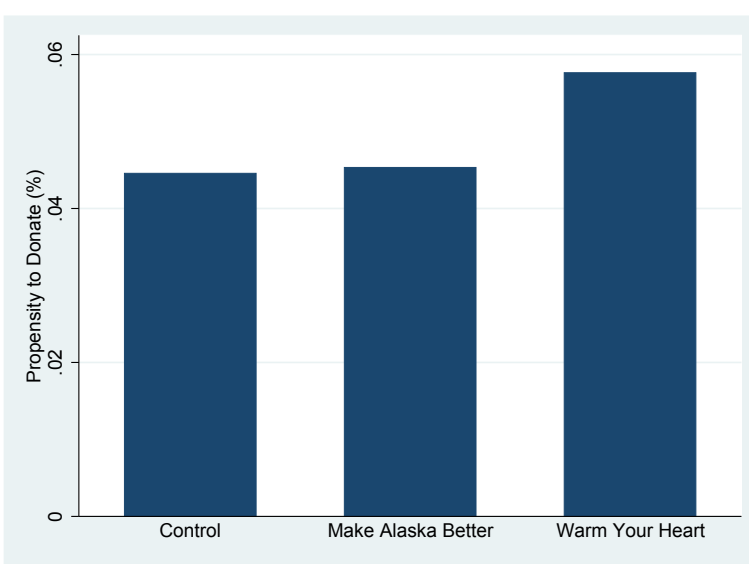

(a) Propensity to Donate

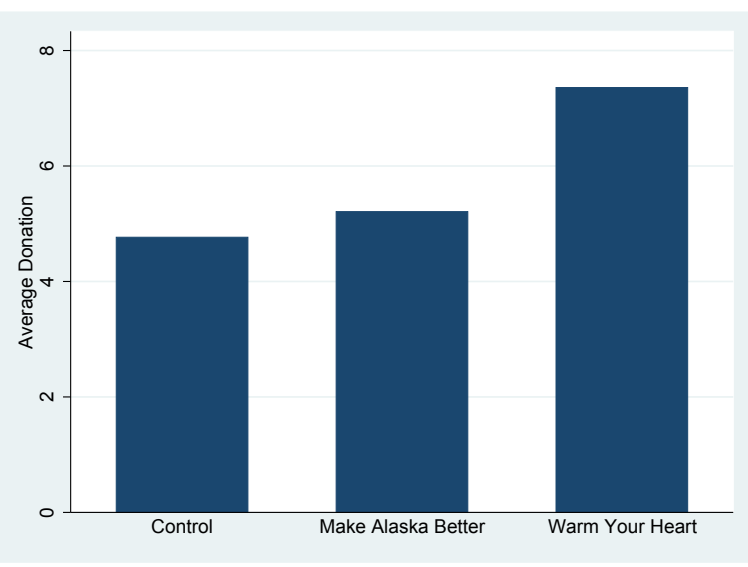

(b) Average Donation Amount 
Table 5: Propensity to Donate: 2013-2014

\begin{tabular}{|c|c|c|c|c|c|c|}
\hline & \multicolumn{4}{|c|}{ Full Data } & \multirow{2}{*}{$\frac{\text { Cold List }}{(5)}$} & \multirow{2}{*}{$\frac{\text { Warm List }}{(6)}$} \\
\hline & $\overline{(1)}$ & $\overline{(2)}$ & $(3)$ & $(4)$ & & \\
\hline \multirow[t]{2}{*}{2014} & .0003 & .0003 & -.0000 & .0003 & .0165 & -.3319 \\
\hline & $(.0005)$ & $(.0005)$ & $(.0005)$ & $(.0005)$ & $(.0010)$ & $(.0078)$ \\
\hline \multirow[t]{2}{*}{ Others $\times 2014$} & .0021 & .0021 & .0021 & .0021 & .0012 & .0174 \\
\hline & $(.0007)$ & $(.0007)$ & $(.0007)$ & $(.0007)$ & $(.0015)$ & $(.0110)$ \\
\hline \multirow[t]{2}{*}{ Self $\times 2014$} & 0.0020 & .0020 & .0020 & .0020 & .0043 & .0365 \\
\hline & $(.0009)$ & $(.0009)$ & $(.0009)$ & $(.0009)$ & $(.0014)$ & $(.0107)$ \\
\hline \multirow[t]{2}{*}{ Donor 2013} & & .8337 & & .832 & & \\
\hline & & $(.0025)$ & & $(.0025)$ & & \\
\hline \multirow[t]{2}{*}{ Female } & & & .0246 & .0034 & & \\
\hline & & & $(.0009)$ & $(.0002)$ & & \\
\hline \multirow[t]{2}{*}{ Under 18} & & & -.0251 & -.0036 & & \\
\hline & & & $(.0014)$ & $(.0003)$ & & \\
\hline \multirow[t]{2}{*}{ Over 49} & & & .0248 & .0025 & & \\
\hline & & & $(.0013)$ & $(.0003)$ & & \\
\hline \multirow[t]{2}{*}{$($ Self-Others $) \times 2014$} & -.00009 & -.00009 & -.0001 & -.0001 & .0031 & .0191 \\
\hline & $(.0009)$ & $(.0009)$ & $(.0009)$ & $(.0009)$ & $(.0014)$ & $(.0106)$ \\
\hline$R^{2}$ & .006 & .685 & .017 & .685 & .010 & .193 \\
\hline$N$ & 966,328 & 966,328 & 966,328 & 966,328 & 917,656 & 48,672 \\
\hline
\end{tabular}


Table 6: Donation Conditional on Giving: 2013-2014

\begin{tabular}{|c|c|c|c|c|c|c|}
\hline & \multicolumn{4}{|c|}{ Full Data } & \multirow{2}{*}{$\frac{\text { Cold List }}{(5)}$} & \multirow{2}{*}{$\frac{\text { Warm List }}{(6)}$} \\
\hline & (1) & (2) & (3) & (4) & & \\
\hline \multirow[t]{2}{*}{2014} & 42.007 & 42.007 & 41.408 & 41.518 & 81.084 & 22.151 \\
\hline & $(3.259)$ & $(3.259)$ & $(3.220)$ & $(3.227)$ & $(5.321)$ & $(3.380)$ \\
\hline \multirow[t]{2}{*}{ Others $\times 2014$} & 5.286 & 5.286 & 5.319 & 5.313 & .8357 & 6.511 \\
\hline & $(5.127)$ & $(5.127)$ & $(5.106)$ & $(5.109)$ & $(7.208)$ & $(5.321)$ \\
\hline \multirow[t]{2}{*}{ Self $\times 2014$} & 10.076 & 10.076 & 10.010 & 10.022 & 13.979 & 9.412 \\
\hline & $(4.287)$ & $(4.287)$ & $(4.241)$ & $(4.249)$ & $(6.875)$ & $(4.288)$ \\
\hline \multirow[t]{2}{*}{ Donor 2013} & & 75.404 & & 69.964 & & \\
\hline & & $(2.882)$ & & $(2.912)$ & & \\
\hline \multirow[t]{2}{*}{ Female } & & & -9.758 & -13.008 & & \\
\hline & & & $(1.888)$ & $(1.896)$ & & \\
\hline \multirow[t]{2}{*}{ Under 18} & & & -47.347 & -41.391 & & \\
\hline & & & $(3.302)$ & $(2.976)$ & & \\
\hline \multirow[t]{2}{*}{ Over 49} & & & 35.119 & 28.698 & & \\
\hline & & & $(3.604)$ & $(3.574)$ & & \\
\hline \multirow[t]{2}{*}{$($ Self-Others $) \times 2014$} & 4.789 & 4.789 & 4.691 & 4.7090 & 13.143 & 2.901 \\
\hline & $(4.839)$ & $(4.839)$ & $(4.819)$ & $(4.8231)$ & $(6.525)$ & $(4.884)$ \\
\hline$R^{2}$ & .036 & .075 & .058 & .091 & 126 & .027 \\
\hline$N$ & 50,392 & 50,392 & 50,392 & 50,392 & 16,908 & 33,484 \\
\hline
\end{tabular}


Figure 7: Treatment Effects by Year

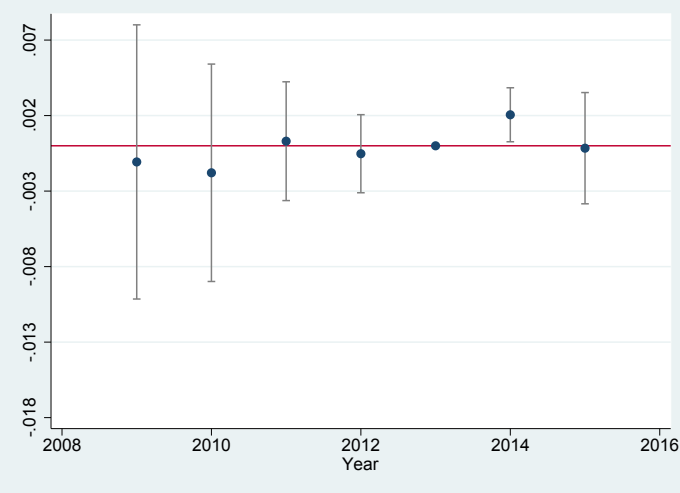

(a) Others: Propensity to Donate

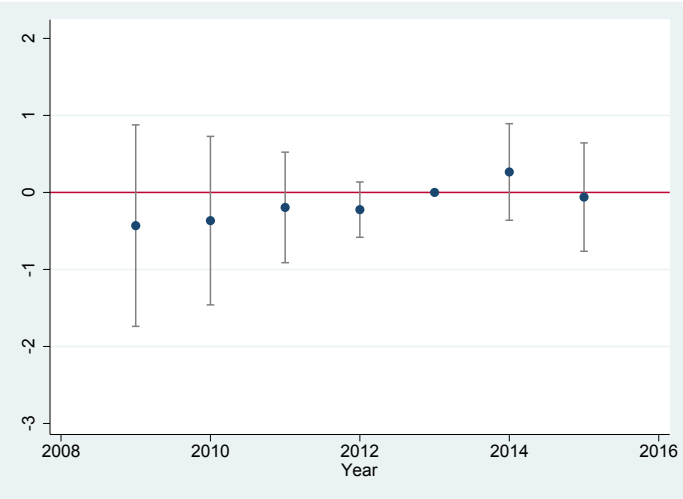

(c) Others: Donation

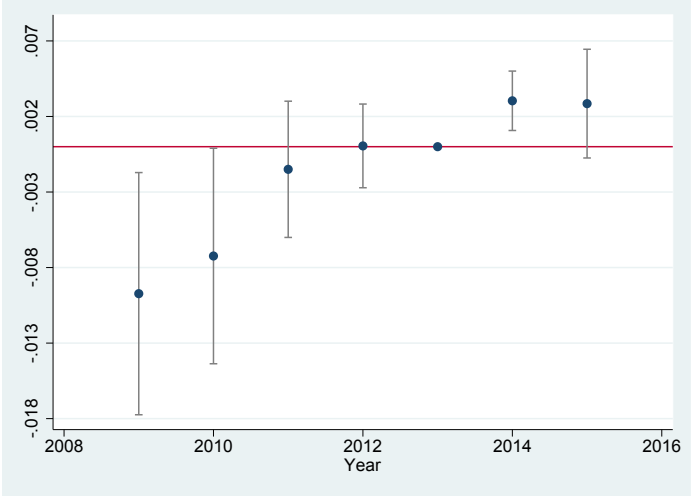

(b) Self: Proptensity to Donate

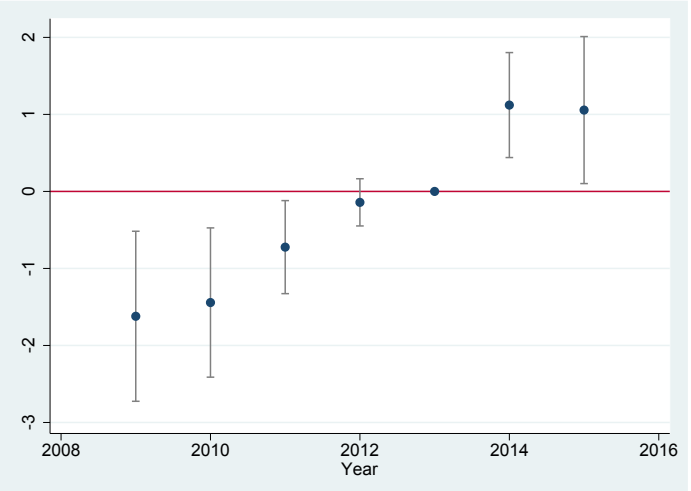

(d) Self: Donation

Note: The reference year is 2013. Standard errors are clustered at the zip code level. For both average donation size and the propensity to give, treatment effects are estimated using a balanced panel and $N=2,120,251$. For the upper panel $R^{2}=.556$ and for the lower panel $R^{2}=.524$. 
Figure 8: Donation, Conditional on Giving by Year

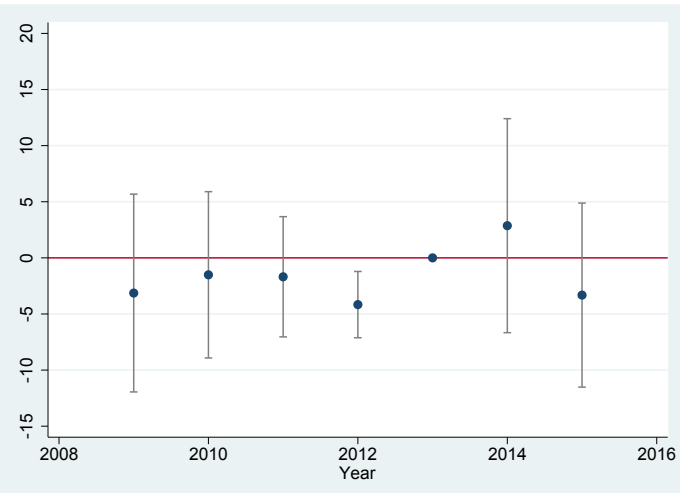

(a) Others

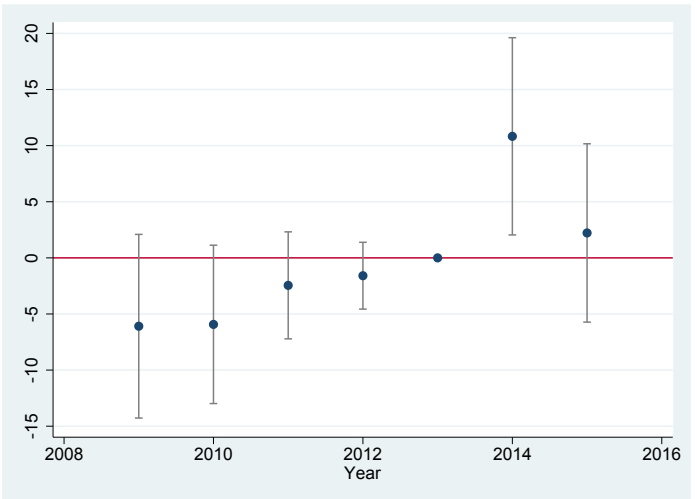

(b) Self

Note: The reference year is 2013. Standard errors are clustered at the zip code level. Data is restricted to those individuals that gave in 2014. $N=128,261$ and $R^{2}=.552$. 
Figure 9: Propensity to Donate by Year: Conditional on Previous Participation

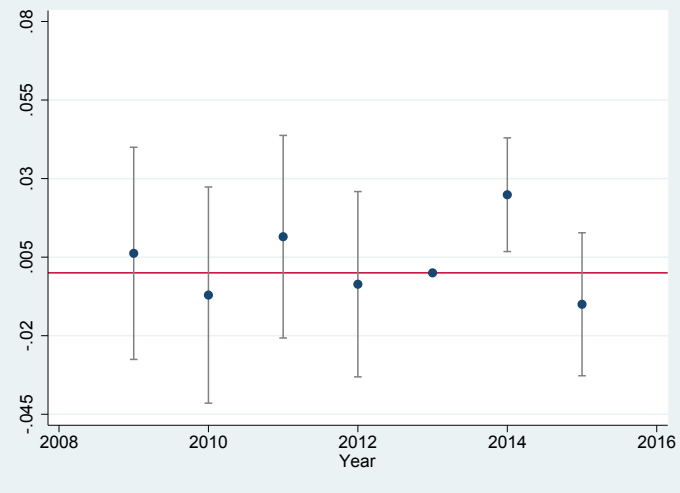

(a) Others: Previously Gave

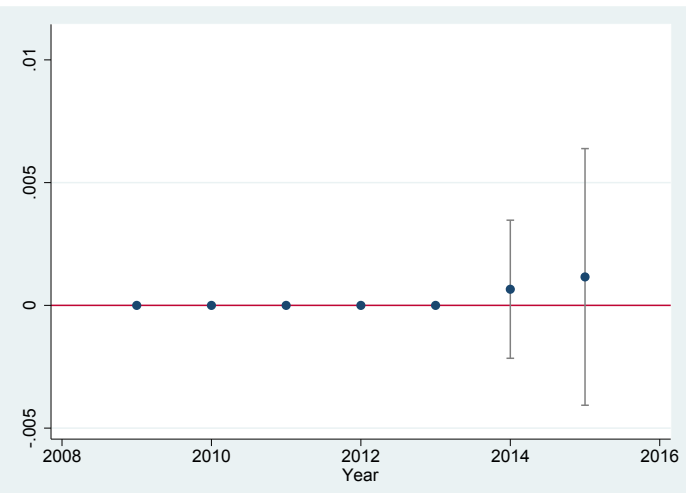

(c) Others: Did Not Previously Give

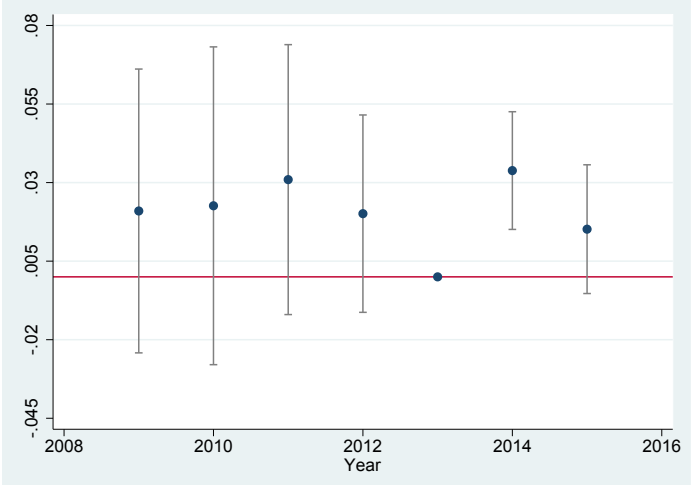

(b) Self: Previously Gave

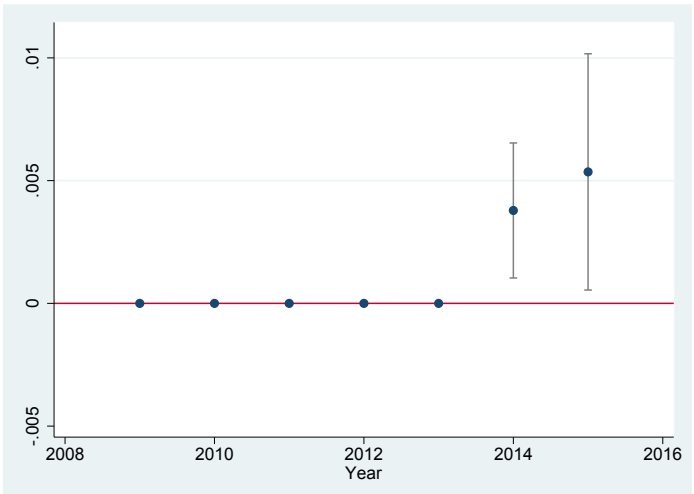

(d) Self: Did Not Previously Give

Note: The reference year is 2013. Standard errors are clustered at the zip code level. "Previously Gave" indicates that a subject gave at least once from 2009 to 2013. Treatment effects are estimated using a balanced panel. For the upper panel $N=175,007$ and $R^{2}=.411$. For the lower panel $N=1,945,244$ and $R^{2}=.208$. 
Figure 10: Donation by Year: Conditional on Previous Participation

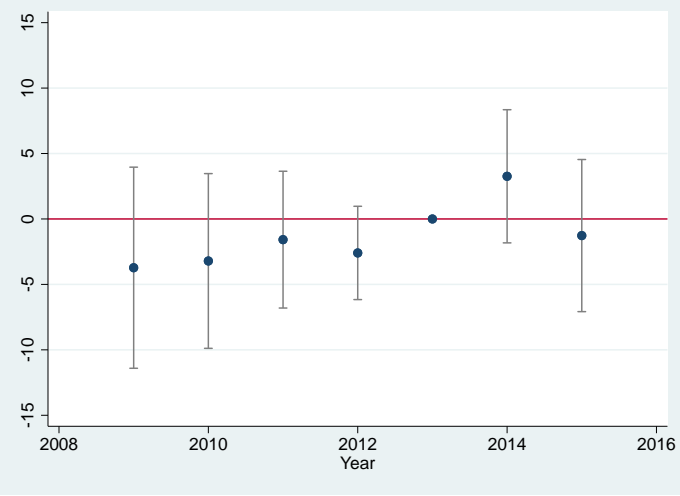

(a) Others: Previously Gave

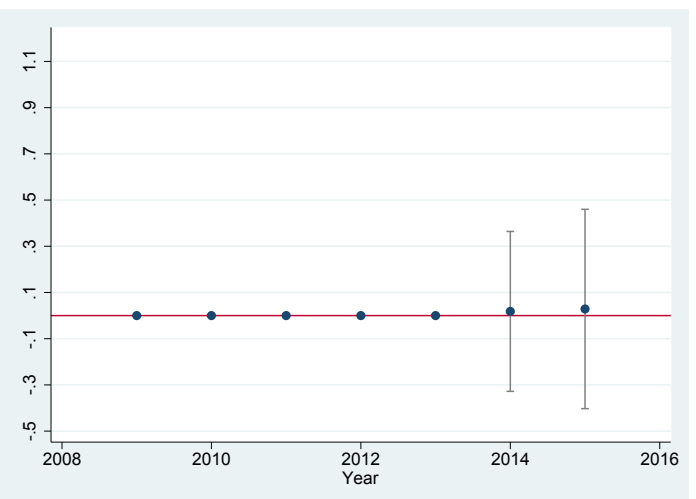

(c) Others: Did Not Previously Give

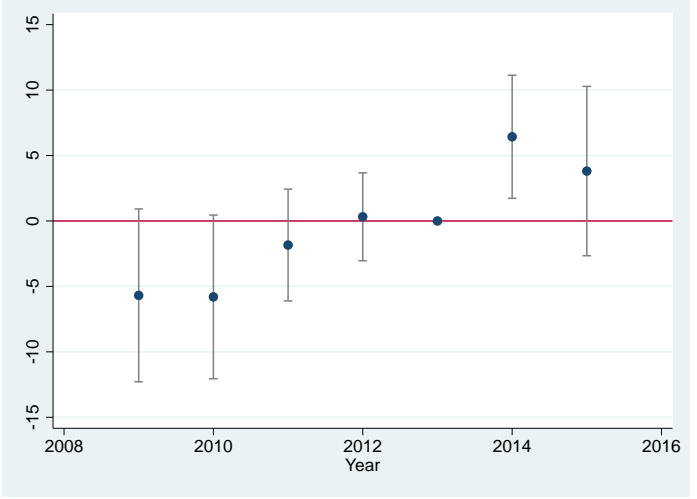

(b) Self: Previously Gave

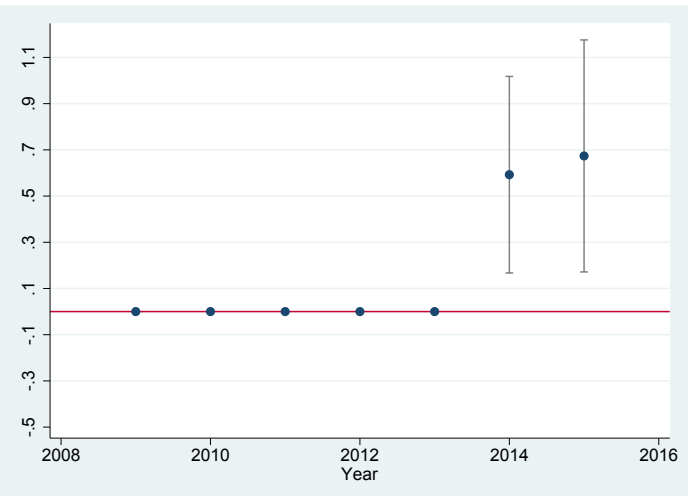

(d) Self: Did Not Previously Give

Note: The reference year is 2013. Standard errors are clustered at the zip code level. "Previously Gave" indicates that a subject gave at least once from 2009 to 2013. Treatment effects are estimated using a balanced panel. For the upper panel $N=175,007$ and $R^{2}=.526$. For the lower panel $N=1,945,244$ and $R^{2}=.198$. 


\section{Appendix}

Table A.1: The 20 Most Popular Recipients

\begin{tabular}{|c|c|c|}
\hline & \# of Donations & Cause Type \\
\hline Beans Café: The Children's Lunchbox & 2253 & Human Services \\
\hline KSKA Alaska Public Media & 1554 & Arts, Culture, and Humanities \\
\hline Abused Women's Aid in Crisis Inc. & 1380 & Human Services \\
\hline Food Bank of Alaska & 1248 & Human Services \\
\hline Alaska Dog and Puppy Rescue & 1208 & Animals \\
\hline Brother Francis Shelter Clare House & 916 & Human Services \\
\hline Friends of Pets & 900 & Animals \\
\hline Planned Parenthood of the Great Northwest & 826 & Health \\
\hline Alaska SPCA & 635 & Animals \\
\hline American Red Cross & 559 & Human Services \\
\hline Fairbanks Animal Shelter Fund & 507 & Animals \\
\hline The Salvation Army & 476 & Human Services \\
\hline Alaska Zoo & 469 & Animals \\
\hline Adopt a Cat & 442 & Animals \\
\hline Fairbanks Community Food Bank & 440 & Human Services \\
\hline Make a Wish Foundation & 425 & Health \\
\hline Aiding Women in Abuse and Rape Emergencies & 412 & Human Services \\
\hline Hospice of Anchorage & 360 & Health \\
\hline Alaska Special Olympics & 348 & Human Services \\
\hline \multirow[t]{2}{*}{ Standing Together Against Rape } & 339 & Public Benefit \\
\hline & Total Dollars & Cause Type \\
\hline Beans Café: The Chilren's Lunchbox & $\$ 161,025$ & Human Services \\
\hline KSKA Alaska Public Media & $\$ 147,500$ & Arts, Culture, and Humanities \\
\hline Food Bank of Alaska & $\$ 117,800$ & Human Services \\
\hline Brother Francis Shelter Clare House & $\$ 90,225$ & Human Services \\
\hline Abused Women's Aid in Crisis & $\$ 85,925$ & Human Services \\
\hline Planed Parenthood of Great Northwest & $\$ 70,275$ & Health \\
\hline Alaska Dog and Puppy Rescue & $\$ 63,000$ & Animals \\
\hline Friends of Pets & $\$ 55,800$ & Animals \\
\hline Alaska SPCA & $\$ 41,875$ & Animals \\
\hline American Red Cross & $\$ 39,725$ & Human Services \\
\hline The Salvation Army & $\$ 38,725$ & Human Services \\
\hline University of Alaska, Fairbanks & $\$ 35,250$ & Education \\
\hline Fairbanks Animal Shelter Fund & $\$ 31,500$ & Animals \\
\hline Fairbanks Community Food Bank Service & $\$ 29,525$ & Human Services \\
\hline Adopt a Cat & $\$ 28,775$ & Animals \\
\hline Hospice of Anchorage & $\$ 28,400$ & Health \\
\hline Kenai Peninsula Food Bank & $\$ 25,950$ & Human Services \\
\hline Aiding Women in abuse and Rape Emergencies & $\$ 25,650$ & Human Services \\
\hline University of Alaska, Anchorage & $\$ 24,600$ & Education \\
\hline Big Brothers Big Sisters of Alaska & $\$ 23,950$ & Human Services \\
\hline
\end{tabular}

Note: All outcomes measured in 2014. 
Table A.2: Donation: 2013-2014 (Cities)

\begin{tabular}{|c|c|c|c|c|c|c|}
\hline & \multicolumn{4}{|c|}{ Full Data } & \multirow{2}{*}{$\frac{\text { Cold List }}{(5)}$} & \multirow{2}{*}{$\frac{\text { Warm List }}{(6)}$} \\
\hline & (1) & $(2)$ & $(3)$ & $(4)$ & & \\
\hline \multirow[t]{2}{*}{2014} & 1.412 & 1.412 & 1.325 & 1.366 & 1.833 & -5.313 \\
\hline & $(.1859)$ & $(.1859)$ & $(.1847)$ & $(.1851)$ & $(.1382)$ & $(1.725)$ \\
\hline \multirow[t]{2}{*}{ Others $\times 2014$} & .0757 & .0757 & .0749 & .0753 & -.0363 & 1.529 \\
\hline & $(.4360)$ & $(.4360)$ & $(.4354)$ & $(.4356)$ & $(.2777)$ & $(4.031)$ \\
\hline \multirow[t]{2}{*}{ Self $\times 2014$} & .6334 & .6334 & .6346 & .6288 & .4461 & 3.883 \\
\hline & $(.347)$ & $(.3478)$ & $(.3457)$ & $(.3466)$ & $(.2650)$ & $(2.739)$ \\
\hline \multirow[t]{2}{*}{ Donor 2013} & & 103.02 & & 102.392 & & \\
\hline & & $(3.914)$ & & $(3.905)$ & & \\
\hline \multirow[t]{2}{*}{ Female } & & & 2.476 & -.5330 & & \\
\hline & & & $(.2009)$ & $(.1545)$ & & \\
\hline \multirow[t]{2}{*}{ Under 18} & & & -5.122 & -1.775 & & \\
\hline & & & $(.4368)$ & $(.2224)$ & & \\
\hline \multirow[t]{2}{*}{ Over 49} & & & 5.913 & 3.119 & & \\
\hline & & & $(.4898)$ & $(.4262)$ & & \\
\hline \multirow[t]{2}{*}{$($ Self-Others $) \times 2014$} & .5577 & .5577 & .5497 & .5535 & .4824 & 2.353 \\
\hline & $(.4918)$ & $(.4918)$ & $(.4908)$ & $(.4913)$ & $(.3304)$ & $(4.220)$ \\
\hline$R^{2}$ & .0026 & .189 & .008 & .190 & .002 & .009 \\
\hline$N$ & 474,682 & 474,682 & 474,682 & 474,682 & 446,302 & 28,380 \\
\hline
\end{tabular}


Table A.3: Propensity to Donate: 2013-2014 (Cities)

\begin{tabular}{|c|c|c|c|c|c|c|}
\hline & \multicolumn{4}{|c|}{ Full Data } & \multirow{2}{*}{$\frac{\text { Cold List }}{(5)}$} & \multirow{2}{*}{$\frac{\text { Warm List }}{(6)}$} \\
\hline & (1) & $(2)$ & $(3)$ & (4) & & \\
\hline \multirow[t]{2}{*}{2014} & .0009 & .0009 & .0005 & .0008 & .0210 & -.3202 \\
\hline & $(.0005)$ & $(.0005)$ & $(.0005)$ & $(.0005)$ & $(.0003$ & $(.0084)$ \\
\hline \multirow[t]{2}{*}{ Others $\times 2014$} & .0011 & .0011 & .0011 & .0011 & -.0007 & .0118 \\
\hline & $(.0007)$ & $(.0007)$ & $(.0007)$ & $(.0007)$ & $(.0016)$ & $(.0134)$ \\
\hline \multirow[t]{2}{*}{ Self $\times 2014$} & .0021 & .0021 & .0021 & .0021 & .0017 & .0305 \\
\hline & $(.0010)$ & $(.0010)$ & $(.0010)$ & $(.0010)$ & $(.0011)$ & $(.0112)$ \\
\hline \multirow[t]{2}{*}{ Donor 2013} & & .8380 & & .8366 & & \\
\hline & & $(.0026)$ & & $(.0026)$ & & \\
\hline \multirow[t]{2}{*}{ Female } & & & .0283 & .0037 & & \\
\hline & & & $(.0012)$ & $(.0004)$ & & \\
\hline \multirow[t]{2}{*}{ Under 18} & & & -.0320 & -.0047 & & \\
\hline & & & $(.0014)$ & $(.0005)$ & & \\
\hline \multirow[t]{2}{*}{ Over 49} & & & .0246 & .0017 & & \\
\hline & & & $(.0017)$ & $(.0005)$ & & \\
\hline \multirow[t]{2}{*}{$($ Self-Others $) \times 2014$} & .0009 & .0009 & .0009 & .0009 & .0024 & .0186 \\
\hline & $(.0010)$ & $(.0010)$ & $(.0010)$ & $(.0010)$ & $(.0019)$ & $(.0128)$ \\
\hline$R^{2}$ & .0032 & .690 & .014 & .690 & .011 & .179 \\
\hline$N$ & 474,682 & 474,682 & 474,682 & 474,682 & 446,302 & 28,380 \\
\hline
\end{tabular}


Table A.4: Donation: 2013-2014 (Matching on Physical and Mailing Zip Code)

\begin{tabular}{|c|c|c|c|c|c|c|}
\hline & \multicolumn{4}{|c|}{ Full Data } & \multirow{2}{*}{$\frac{\text { Cold List }}{(5)}$} & \multirow{2}{*}{$\frac{\text { Warm List }}{(6)}$} \\
\hline & (1) & $(2)$ & $(3)$ & (4) & & \\
\hline \multirow[t]{2}{*}{2014} & .7357 & .7357 & .6591 & .6983 & 1.277 & -10.470 \\
\hline & $(.1951)$ & $(.1951)$ & $(.1948)$ & $(.1950)$ & $(.1154)$ & $(3.018)$ \\
\hline \multirow[t]{2}{*}{ Others $\times 2014$} & .4311 & .4311 & .4352 & .4331 & .1646 & 5.992 \\
\hline & $(.3141)$ & $(.3141)$ & $(.3144)$ & $(.3143)$ & $(.1953)$ & $(4.146)$ \\
\hline \multirow[t]{2}{*}{ Self $\times 2014$} & .9717 & .9717 & .9651 & .9685 & .7135 & 7.703 \\
\hline & $(.2919)$ & $(.2919)$ & $(.2913)$ & $(.2916)$ & $(.2204)$ & $(3.401)$ \\
\hline \multirow[t]{2}{*}{ Donor 2013} & & 94.286 & & 93.709 & & \\
\hline & & $(3.432)$ & & $(3.410)$ & & \\
\hline \multirow[t]{2}{*}{ Female } & & & 2.119 & -.2209 & & \\
\hline & & & $(.1253)$ & $(.1106)$ & & \\
\hline \multirow[t]{2}{*}{ Under 18} & & & -3.649 & -1.244 & & \\
\hline & & & $(.3346)$ & $(.1478)$ & & \\
\hline \multirow[t]{2}{*}{ Over 49} & & & 5.183 & 2.529 & & \\
\hline & & & $(.4036)$ & $(.2925)$ & & \\
\hline \multirow[t]{2}{*}{$($ Self-Others $) \times 2014$} & .5406 & .5406 & .5298 & .5353 & .5489 & 1.710 \\
\hline & $(.3282)$ & $(.3282)$ & $(.3279)$ & $(.3280)$ & $(.2451)$ & $(3.247)$ \\
\hline$R^{2}$ & .004 & .192 & .010 & .192 & .003 & .018 \\
\hline$N$ & 793,714 & 793,714 & 793,714 & 793,714 & 753,280 & 40,434 \\
\hline
\end{tabular}


Table A.5: Propensity to Donate: 2013-2014 (Matching on Physical and Mailing Zip Code)

\begin{tabular}{|c|c|c|c|c|c|c|}
\hline & \multicolumn{4}{|c|}{ Full Data } & \multirow{2}{*}{$\frac{\text { Cold List }}{(5)}$} & \multirow{2}{*}{$\frac{\text { Warm List }}{(6)}$} \\
\hline & (1) & $(2)$ & $(3)$ & (4) & & \\
\hline \multirow[t]{2}{*}{2014} & .0004 & .0004 & .0000 & .0003 & .0160 & -.3238 \\
\hline & $(.0006)$ & $(.0006)$ & $(.0006)$ & $(.0006)$ & $(.0012)$ & $(.0080)$ \\
\hline \multirow[t]{2}{*}{ Others $\times 2014$} & .0020 & .0020 & .0020 & .0020 & .0015 & .0149 \\
\hline & $(.0009)$ & $(.0009)$ & $(.0009)$ & $(.0009)$ & $(.0017)$ & $(.0118)$ \\
\hline \multirow[t]{2}{*}{ Self $\times 2014$} & .0023 & .0023 & .0023 & .0023 & .0051 & .0352 \\
\hline & $(.0010)$ & $(.0010)$ & $(.0010)$ & $(.0010)$ & $(.0016)$ & $(.0110)$ \\
\hline \multirow[t]{2}{*}{ Donor 2013} & & .8371 & & .8357 & & \\
\hline & & $(.0026)$ & & $(.0026)$ & & \\
\hline \multirow[t]{2}{*}{ Female } & & & .0242 & .0033 & & \\
\hline & & & $(.0010)$ & $(.0003)$ & & \\
\hline \multirow[t]{2}{*}{ Under 18} & & & -.0250 & -.0036 & & \\
\hline & & & $(.0015)$ & $(.0003)$ & & \\
\hline \multirow[t]{2}{*}{ Over 49} & & & .0261 & .0025 & & \\
\hline & & & $(.0014)$ & $(.0004)$ & & \\
\hline \multirow[t]{2}{*}{$($ Self-Others $) \times 2014$} & .0003 & .0003 & .0003 & .0003 & .0036 & .0203 \\
\hline & $(.0010)$ & $(.0010)$ & $(.0010)$ & $(.0010)$ & $(.0015)$ & $(.0116)$ \\
\hline$R^{2}$ & .007 & .690 & .018 & .690 & .010 & .189 \\
\hline$N$ & 793,714 & 793,714 & 793,714 & 793,714 & 753,280 & 40,434 \\
\hline
\end{tabular}


Table A.6: Donation: 2013-2014 (No P.O. Boxes)

\begin{tabular}{|c|c|c|c|c|c|c|}
\hline & \multicolumn{4}{|c|}{ Full Data } & \multirow{2}{*}{$\frac{\text { Cold List }}{(5)}$} & \multirow{2}{*}{$\frac{\text { Warm List }}{(6)}$} \\
\hline & $(1)$ & $(2)$ & $(3)$ & $(4)$ & & \\
\hline \multirow[t]{2}{*}{2014} & .7651 & .7651 & .6882 & .7269 & 1.367 & -11.102 \\
\hline & $(.2208)$ & $(.2208)$ & $(.2199)$ & $(.2202)$ & $(.1357)$ & $(2.980)$ \\
\hline \multirow[t]{2}{*}{ Others $\times 2014$} & .4290 & .4290 & .4336 & .4312 & .1281 & 6.256 \\
\hline & $(.3479)$ & $(.3479)$ & $(.3482)$ & $(.3481)$ & $(.2236)$ & $(4.139)$ \\
\hline \multirow[t]{2}{*}{ Self × 2014} & 1.073 & 1.073 & 1.067 & 1.070 & .7280 & 8.978 \\
\hline & $(.3190)$ & $(.3190)$ & $(.3183)$ & $(.3186)$ & $(.2299)$ & $(3.400)$ \\
\hline \multirow{2}{*}{ Donor 2013} & & 94.614 & & 94.046 & & \\
\hline & & $(3.624)$ & & $(3.605)$ & & \\
\hline \multirow[t]{2}{*}{ Female } & & & 2.128 & -.2949 & & \\
\hline & & & $(.1307)$ & $(.1136)$ & & \\
\hline \multirow[t]{2}{*}{ Under 18} & & & -3.795 & -1.263 & & \\
\hline & & & $(.3664)$ & $(.1568)$ & & \\
\hline \multirow[t]{2}{*}{ Over 49} & & & 5.282 & 2.621 & & \\
\hline & & & $(.4049)$ & $(.3057)$ & & \\
\hline \multirow[t]{2}{*}{$($ Self-Others $) \times 2014$} & .6647 & .6447 & .6336 & .6392 & .5998 & 2.721 \\
\hline & $(.3540)$ & $(.3540)$ & $(.3537)$ & $(.3538)$ & $(.2569)$ & $(3.307)$ \\
\hline$R^{2}$ & .003 & .191 & .009 & .192 & .002 & .015 \\
\hline$N$ & 779,002 & 779,002 & 779,002 & 779,002 & 738,182 & 40,820 \\
\hline
\end{tabular}


Table A.7: Propensity to Donate: 2013-2014 (No P.O. Boxes)

\begin{tabular}{|c|c|c|c|c|c|c|}
\hline & \multicolumn{4}{|c|}{ Full Data } & \multirow{2}{*}{$\frac{\text { Cold List }}{(5)}$} & \multirow{2}{*}{$\frac{\text { Warm List }}{(6)}$} \\
\hline & $(1)$ & $(2)$ & $(3)$ & $(4)$ & & \\
\hline \multirow[t]{2}{*}{2014} & .0005 & .0005 & .0001 & .0004 & .0171 & -.3275 \\
\hline & $(.0005)$ & $(.0005)$ & $(.0005)$ & $(.0005)$ & $(.0012)$ & $(.0088)$ \\
\hline \multirow[t]{2}{*}{ Others $\times 2014$} & .0028 & .0028 & .0028 & .0028 & .0016 & .0211 \\
\hline & $(.0009)$ & $(.0009)$ & $(.0009)$ & $(.0009)$ & $(.0017)$ & $(.0120)$ \\
\hline \multirow[t]{2}{*}{ Self $\times 2014$} & .0025 & .0025 & .0025 & .0025 & .0047 & .0399 \\
\hline & $(.0010)$ & $(.0009)$ & $(.0009)$ & $(.0009)$ & $(.0015)$ & $(.0113)$ \\
\hline \multirow{2}{*}{ Donor 2013} & & .8369 & & .8355 & & \\
\hline & & $(.0027)$ & & $(.0027)$ & & \\
\hline \multirow[t]{2}{*}{ Female } & & & .0251 & .0035 & & \\
\hline & & & $(.0010)$ & $(.0002)$ & & \\
\hline \multirow[t]{2}{*}{ Under 18} & & & -.0262 & -.00372 & & \\
\hline & & & $(.0017)$ & $(.0004)$ & & \\
\hline \multirow[t]{2}{*}{ Over 49} & & & .0257 & .0021 & & \\
\hline & & & $(.0014)$ & $(.0004)$ & & \\
\hline \multirow[t]{2}{*}{$($ Self-Others $) \times 2014$} & -.0002 & -.0002 & -.0003 & -.0002 & .0031 & .0187 \\
\hline & $(.0010)$ & $(.0010)$ & $(.0010)$ & $(.0010)$ & $(.0015)$ & $(.0107)$ \\
\hline$R^{2}$ & .005 & .687 & .015 & .687 & .010 & .183 \\
\hline$N$ & 779,002 & 779,002 & 779,002 & 779,002 & 738,182 & 40,820 \\
\hline
\end{tabular}


Table A.8: Donation: 2013-2014 (Zip Mismatch Only)

\begin{tabular}{|c|c|c|c|c|c|c|}
\hline & \multicolumn{4}{|c|}{ Full Data } & \multirow{2}{*}{$\frac{\text { Cold List }}{(5)}$} & \multirow{2}{*}{$\frac{\text { Warm List }}{(6)}$} \\
\hline & $(1)$ & (2) & $(3)$ & (4) & & \\
\hline \multirow[t]{2}{*}{2014} & .9810 & .9810 & .9166 & .9492 & 1.595 & -9.817 \\
\hline & $(.2403)$ & $(.2403)$ & $(.2375)$ & $(.2380)$ & $(.1575)$ & $(3.332)$ \\
\hline \multirow[t]{2}{*}{ Others $\times 2014$} & .1700 & .1700 & .1787 & .1743 & -.0550 & 3.072 \\
\hline & $(.6612)$ & $(.6612)$ & $(.6575)$ & $(.6594)$ & $(.5647)$ & $(5.921)$ \\
\hline \multirow[t]{2}{*}{ Self $\times 2014$} & .9505 & .9506 & .9508 & .9507 & .4547 & 9.645 \\
\hline & $(.6935)$ & $(.6935)$ & $(.6899)$ & $(.6917)$ & $(.3675)$ & $(9.602)$ \\
\hline \multirow[t]{2}{*}{ Donor 2013} & & 99.908 & & 99.5643 & & \\
\hline & & $(6.576)$ & & $(6.550)$ & & \\
\hline \multirow[t]{2}{*}{ Female } & & & 2.813 & -.2855 & & \\
\hline & & & $(.4828)$ & $(.2836)$ & & \\
\hline \multirow[t]{2}{*}{ Under 18} & & & -3.845 & -1.151 & & \\
\hline & & & $(.7308)$ & $(.4125)$ & & \\
\hline \multirow[t]{2}{*}{ Over 49} & & & 3.926 & 1.938 & & \\
\hline & & & $(.5322)$ & $(.4867)$ & & \\
\hline \multirow[t]{2}{*}{$($ Self-Others $) \times 2014$} & .4846 & .7804 & .7720 & .7763 & .5098 & 6.573 \\
\hline & $(.8237)$ & $(.7916)$ & $(.8908)$ & $(.8934)$ & $(.6359)$ & $(10.249)$ \\
\hline$R^{2}$ & .005 & .184 & .009 & .184 & .003 & .045 \\
\hline$N$ & 105,440 & 105,440 & 105,440 & 105,440 & 100,064 & 5,376 \\
\hline
\end{tabular}


Table A.9: Propensity to Donate: 2013-2014 (Zip Mismatch Only)

\begin{tabular}{|c|c|c|c|c|c|c|}
\hline & \multicolumn{4}{|c|}{ Full Data } & \multirow{2}{*}{$\frac{\text { Cold List }}{(5)}$} & \multirow{2}{*}{$\frac{\text { Warm List }}{(6)}$} \\
\hline & $(1)$ & (2) & $(3)$ & (4) & & \\
\hline \multirow[t]{2}{*}{2014} & -.0006 & -.0006 & -.0009 & -.0006 & .0189 & -.3597 \\
\hline & $(.0011)$ & $(.0011)$ & $(.0011)$ & $(.0011)$ & $(.0013)$ & $(.0222)$ \\
\hline \multirow[t]{2}{*}{ Others $\times 2014$} & .0018 & .0018 & .0019 & .0019 & -.0011 & .0179 \\
\hline & $(.0015)$ & $(.0015)$ & $(.0015)$ & $(.0015)$ & $(.0029)$ & $(.0269)$ \\
\hline \multirow[t]{2}{*}{ Self $\times 2014$} & .0005 & .0005 & .0005 & .0005 & -.0013 & .0248 \\
\hline & $(.0024)$ & $(.0024)$ & $(.0024)$ & $(.0024)$ & $(.0028)$ & $(.0264)$ \\
\hline \multirow[t]{2}{*}{ Donor 2013} & & .8247 & & .8232 & & \\
\hline & & $(.0056)$ & & $(.0057)$ & & \\
\hline \multirow[t]{2}{*}{ Female } & & & .0300 & .0044 & & \\
\hline & & & $(.0023)$ & $(.0008)$ & & \\
\hline \multirow[t]{2}{*}{ Under 18} & & & -.0253 & -.0030 & & \\
\hline & & & $(.0031)$ & $(.0009)$ & & \\
\hline \multirow[t]{2}{*}{ Over 49} & & & .0191 & .0027 & & \\
\hline & & & $(.0027)$ & $(.0010)$ & & \\
\hline \multirow[t]{2}{*}{$($ Self-Others $) \times 2014$} & -.0013 & -.0014 & -.0014 & -.0014 & -.0002 & .0196 \\
\hline & $(.0023)$ & $(.0022)$ & $(.0023)$ & $(.0023)$ & $(.0036)$ & $(.0232)$ \\
\hline$R^{2}$ & .009 & .680 & .018 & .680 & .013 & .215 \\
\hline$N$ & 105,440 & 105,440 & 105,440 & 105,440 & 100,064 & 5,376 \\
\hline
\end{tabular}

